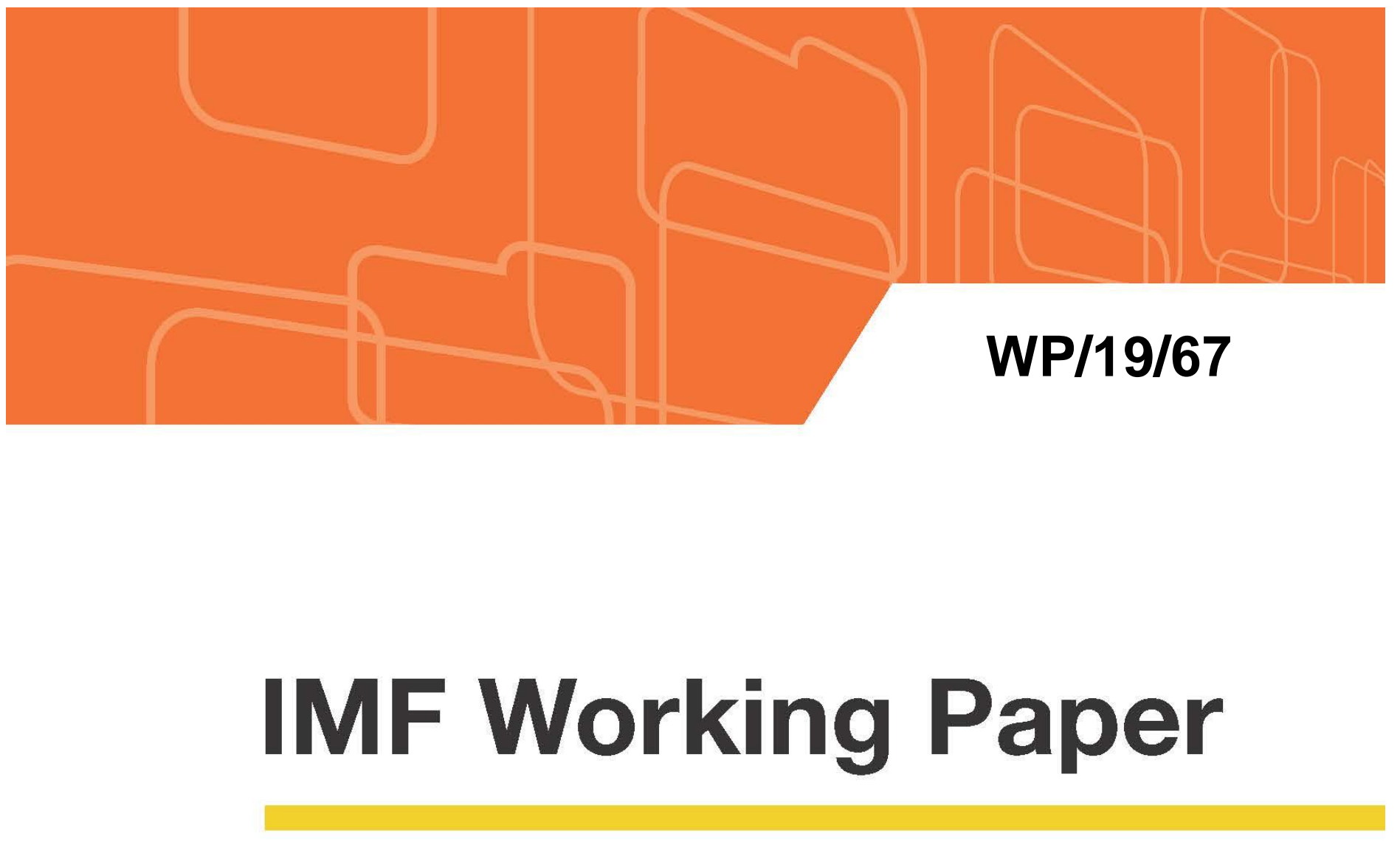

\title{
The Structural Determinants of the Labor Share in Europe
}

\author{
by Dilyana Dimova
}

IMF Working Papers describe research in progress by the author(s) and are published to elicit comments and to encourage debate. The views expressed in IMF Working Papers are those of the author(s) and do not necessarily represent the views of the IMF, its Executive Board, or IMF management.

$$
\text { I N T E R N A T I O N A L M O N E T A R Y F U N D }
$$




\title{
IMF Working Paper
}

European Department

\section{The Structural Determinants of the Labor Share in Europe}

Prepared by Dilyana Dimova*

Authorized for distribution by Laura Papi

March 2019

\section{IMF Working Papers describe research in progress by the author(s) and are published to elicit comments and to encourage debate. The views expressed in IMF Working Papers are those of the author(s) and do not necessarily represent the views of the IMF, its Executive Board, or IMF management.}

\begin{abstract}
The labor share in Europe has been on a downward trend. This paper finds that the decline is concentrated in manufacture and among low- to mid-skilled workers. The shifting nature of employment away from full-time jobs and a rollback of employment protection, unemployment benefits and unemployment benefits have been the main contributors.

Technology and globalization hurt sectors where jobs are routinizable but helped others that require specialized skills. High-skilled professionals gained labor share driven by productivity aided by flexible work environments, while low- and mid-skilled workers lost labor share owing to globalization and the erosion of labor market safety nets.
\end{abstract}

JEL Classification Numbers: E25, F66, J31, O33

Keywords: labor share, technology, employment policies, globalization

Author's E-Mail Address: ddimova@imf.org

\footnotetext{
* The author is grateful for comments and suggestions from Craig Beaumont, Emil Stavrev and seminar participants. Cristina Batog provided excellent research assistance. Any errors remain my own.
} 


\section{CONTENTS}

ABSTRACT _ _ _ _ _ 2

I. INTRODUCTION___________ 4

II. LITERATURE REVIEW ___________________________ 6

III. MAJOR LABOR TRENDS IN THE EU ____ 9

A. Evolution of Labor Share by Skill and by Industry Sectors ___ 9

B. Shift-Share Analysis____ 12

C. The Changing Landscape of Structural Factors in the EU Labor Market ___ 14

IV. METHODOLOGY ___ 17

A. Data _ 17

B. Cross-Country Panel Analysis ____ 18

V. RESULTS ______ 20

A. Expected Contribution of Structural Factors ___ 20

B. Sectoral Labor Share ___ 21

C. Skill Labor Share ___ 31

VI. SUMMARY AND POLICY IMPLICATIONS ___ 35

FIGURES

1. The Labor Share in the EU ___ 5

2. Evolution of Labor Share by Skill Category ___ 10

3. Evolution of Labor Share in Goods Producing Industries _____ 11

4. Evolution of Labor Share in Service Industries ___ 11

5. Shift Share Analysis by Industry and Skill Category ____ 13

6. The Evolution of Labor Market Factors ___ 15

7. The Evolution of Goods Market Factors ___ 16

8. Contribution of Structural Factors to Labor Share Changes in Manufacturing Sectors ___ 24

9. Contribution of Structural Factors to Labor Share Changes in Agriculture and

Trade Industries ___ 25

10. Contribution of Structural Factors to Labor Share Changes in Services

Industries __ 26

11. Contribution of Structural Factors to Labor Share Changes by Skill Category _____ 33

TABLES

1. Structural Factors Contribution in Manufacturing Sectors _____ 29

2. Structural Factors Contribution in Agriculture and Trade Sectors ____ 30

3. Structural Factors Contribution in Service Sectors____ 31

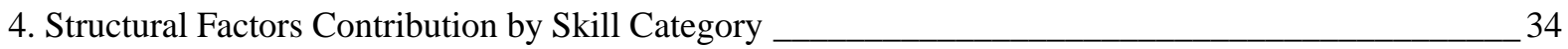

\section{APPENDICES}

I. Data Description

REFERENCES

References 


\section{INTRODUCTION}

The value-added share accrued to labor commonly known as the labor share-the ratio of labor compensation (wages and benefits) to national income - has been on a downward trend in the EU in the last couple of decades (Figure 1). This trend is observed both in recession-hit Advanced Economies (AE) like Ireland, Portugal and Spain as well as in economicallyprosperous Germany and the Netherlands (Figure 1, upper panels), and began around 201213 after the Great Recession (GR). In New Member States (NMS), Estonia, Hungary, Latvia and Lithuania experienced a decline in 2009-15 and are on the rebound (Figure 1, lower panels). Other NMS economies such as Croatia, Poland and Romania have yet to return to their 2002 levels. The positive exception is Bulgaria whose labor share has been on an upward trend due to an economic deepening from relatively low levels.

This paper looks at the evolution of the labor share by industry and by skill level and considers the effect of various structural factors on the EU-wide stagnation and erosion of the labor share. Following Dao et al. (2017), first a shift-share analysis is used to demonstrate the extent to which the downward trend in the labor share is driven by within-sector/skill category declines or by changes across sectors/skill category. The analysis establishes that within-sector/skill category changes account for the majority of labor share fluctuations and provides justification for the structural factor analysis. Then the paper quantifies the extent to which structural drivers track changes in the labor share in $28 \mathrm{EU}$-member countries, representing both advanced economies and transitional economies, in a cross-country panel study that uses disaggregated data for twelve industry sectors and three skill categories.

The structural factors encompass three categories: employment structure indicators (selfemployment share, part-time employment share and temporary employment); labor market policies (employment protection, unemployment benefits and unionization rate), and goods market structure (technology proxied by the relative price of investment goods, import penetration standing for globalization and two global value chains indicators). Technological advancement has reduced the relative price of investment goods and lowered firms' cost of capital thereby giving them strong incentives to replace labor with capital and may be stronger for "routinizable" occupations (Bentolila and Saint-Paul, 2003; Arpaia et al., 2009; Driver and Muñoz-Bugarin, 2010; Raurich et al., 2012; Hutchinson and Persyn, 2012, Abdih and Danninger, 2017). Globalization and labor market policies have effected change on the workers' value-added. Many manufacturing industries have experienced steep declines in unionization; a high level of competition from imports; and a high intensity of foreign input usage (Abdih and Danninger, 2017). Economic integration has promoted the relocation of lower-skill labor-intensive stages of production to cheaper locations in emerging and developing economies depressing the labor share in advanced and emerging economies (Dao et al., 2017). Participation in global value chains has eroded the labor share in advanced and 
emerging market economies by offshoring production of intermediate goods and later of services and thereby reducing the demand for mid-skilled jobs (Amiti and Wei, 2009).

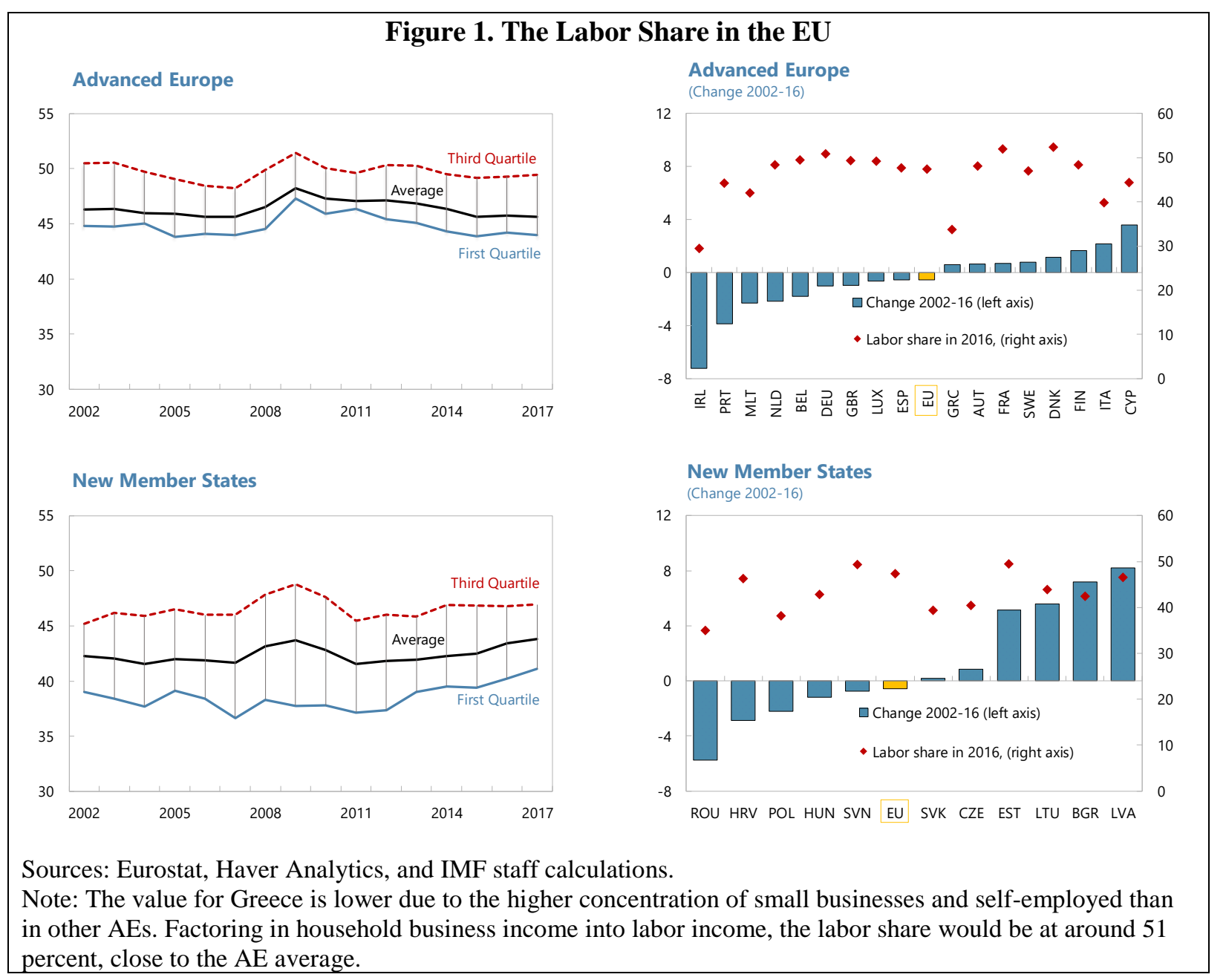

The contribution of this paper to the existing literature is three-fold. First, it goes beyond a singular focus on a handful of indicators and instead considers an array of structural factors to capture more completely their contribution to the labor share erosion. Second, it takes a disaggregated approach that considers labor changes in European economies by sector and by skill category. Lastly, it also factors in the effect of various cyclical components. The paper focuses on two questions: How has the labor share evolved in Europe and whether this evolution has been tilted disproportionally toward some sectors or skill categories? What are the key structural drivers of the labor share evolution and do their contribution vary by economies, industries, and skill groups?

The empirical analysis suggests that labor share decline is heavily concentrated in goods production and among low- to mid-skilled workers (2-5 percentage points on average). In contrast, service industries held or gained labor share and this gain likely overlaps with the progress made by high-skilled workers. Changes in the labor share are associated with several 
structural factors. Employment factors such as a rise in part-time employment and in temporary contracts are among the main contributors to lower labor share in almost all countries and sectors. Labor market policy trends such as a decline in unemployment benefits and in unionization, coupled with a steady erosion of employment protection contribute up to 1 percentage point loss in several sectors and in countries with shrinking labor share such as Germany and the Netherlands.

Technology depressed the labor share only in sectors such as trade and travel where jobs are relatively easy to routinize but helped raise productivity of specialized workers in diverse fields such as agriculture, construction and professional services. Globalization in the form of import penetration helped raise the labor share in transitional economies where workers with relatively low income competed with their higher-paid advanced economy peers. Rising productivity has driven the labor share of high-skilled workers up by 1 percentage point on average, but the productivity of mid- and low-skilled workers stagnated. Their labor share shrank primarily owing to globalization aided by the erosion of unemployment benefits and employment protection.

The next section presents a literature overview and the following section discusses major trends in the labor share in the EU. The subsequent two sections explain the methodology and present the findings. The last section offers policy recommendations and concludes.

\section{LiteratURE REVIEW}

Declining labor share has been documented in a host of recent studies, namely Alvaredo et al. (2017), Dao et al. (2017) and Houngbonon and Da-Costa (2017). They note that declining labor share tends to raise income inequality, because wealth distribution is typically more concentrated than labor endowment and hinders growth because it reduces household consumption. An obvious explanation for changes in the aggregate labor share could be sectoral change where industries with traditionally lower labor share rise in their share of value-added. de Serres et al. (2002) find that most changes in France, Italy, and the US can be accounted for by sectoral change and for Germany they find that the downward trend in the labor share is fully explained by a shift towards industries with lower share. Their explanation is a structural change where manufacturing accounts for less in aggregate valueadded while the relative value-added in services increase. Garrido Ruiz (2005) and Arpaia et al. (2009) confirm this for individual countries and over selected periods.

Beyond intersectoral reallocation, there is broad consensus that the labor share has declined in most advanced economies and in some emerging economies over the last two decades and that structural forces may be partly behind this decline (Dao et al. 2017). Decreasing labor share tends to be associated with rising inequality. Within the workforce, lower-skilled 
workers have borne the brunt of the fall in labor share amid evidence of persistent declines in middle-skilled occupations and income losses for middle-skilled workers in advanced economies (Autor and Dorn 2013; Goos, Manning, and Salomons, 2014). Besides, capital ownership is typically concentrated among the top of the income distribution (Wolff, 2010) and hence an increase in the share of returns accruing to capital tends to raise income inequality. Some of the likely factors that contribute to this secular decline are considered in more detail below.

Technological changes are often presented as the main culprit, with some authors seeing the role of capital accumulation and capital-augmenting technical change as determinants of the evolution of the labor share (Bentolila and Saint-Paul, 2003; Arpaia et al., 2009; Driver and Muñoz-Bugarin, 2010; Raurich et al., 2012; Hutchinson and Persyn, 2012). Lawless and Whelan (2011) suggest that technological change is the driving force behind the decreasing income share of labor in Europe. Arpaia et al. (2009) and Karabarbounis and Neiman (2014) argue that one reason for the shift in the income distribution is capital-augmenting technological progress. They find that unskilled labor is a substitute to capital while skilled labor and capital are complements. The European Commission (2007) finds that information and communication technology (ICT). Has insignificant impact on the labor share. Guscina (2007) has similar results with respect to capital and ICT and discusses additionally a structural break in 1985 for OECD countries likely because before the computer revolution technological progress was labor-augmenting but turned to be capital-augmenting in 1985 . Jaumotte and Tytell (2008) find no significant overall impact of technology on the labor share but evidence for capital-augmenting technological progress is also found in Bentolia and Saint-Paul (2003).

ICT tends to influence labor not only through substitutability of labor with ICT and foreign work, but also through lowering rents of workers as monitoring technology improves (Schneider, 2011a). Using a country-industry panel for Western Europe Schneider (2011b) focuses on long and short-run labor share changes within industries and finds a large and time-persistent impact of increasing globalization on the labor share, especially if the withinindustry changes are considered. Openness seems to be the driving force for downward movements in the industry level labor share while technological and institutional forces impact the share positively. Furthermore, while investments into information and communication technology have a negative impact on the labor share as it enables higher economic integration which lowers the labor share.

Abdih and Danninger (2017) find that in addition to changes in labor institutions, technological change and different forms of trade integration lowered the labor share. The fall is largest, on average, in industries that saw: a high initial intensity of "routinizable" occupations; steep declines in unionization; a high level of competition from imports; and a high intensity of foreign input usage. Quantitatively, the bulk of the effect comes from 
changes in technology that are linked to the automation of routine tasks, followed by trade globalization. This paper finds similar results, especially in agriculture and construction as well as some high-skilled occupations.

Economic integration has brought about domestic factor reallocation in response to import competition; promoted the relocation of lower-skill, labor-intensive stages of production to cheaper locations in emerging and developing economies; and may have lowered the relative cost of capital (Dao et al., 2017). Studies typically also find smaller negative effects of globalization on the labor share in high-income countries, possibly due to the intensification of competition and the entry of labor-abundant countries into the global economy which may have worked as a wage-moderating factor (ILO, 2008).

Karabarbounis and Neiman (2013) instead emphasize that the cost of capital, captured by the relative price of investment goods, has fallen relative to the cost of labor, driven especially by rapid declines in quality-adjusted equipment prices of information and communication technologies. Autor et al. (2017) propose a new "superstar firm" model that emphasizes the role of firm heterogeneity in the dynamics of the aggregate labor share. They hypothesize that industries are increasingly characterized by a "winner take most" feature where one firm (or a small number of firms) can gain a very large share of the market. As the importance of superstar firms increases, the aggregate labor share will tend to fall.

Furthermore, participation in global value chains can simultaneously lead to lower labor share in advanced and emerging market economies and explores empirically whether trade and financial integration in general - and participation in global value chains in particularis correlated with the evolution of labor share. The rising trend in global value chain participation-measured as the sum of so-called forward and backward linkages in vertical specialization, a widely-used measure of participation in global value chains. Among advanced economies, this reflects an offshoring of production of intermediate goods, and since the late 1990s a steady increase in offshoring of services as well (Amiti and Wei, 2009). Among emerging market and developing economies, it reflects an increase in importing components for assembly and re-exportation in global value chains (Hummels et al., 2014; Koopman, Wang, and Wei, 2014).

The regulation of labor and product markets determines the size of profits and their distribution between capital and labor (Blanchard and Giavazzi, 2003). Changes in product market structure that favor agglomeration, for example, may have increased concentration across a number of industries, raising profit shares and lowering the labor share of income (Council of Economic Advisers, 2016). Ciminelli et al. (2018) assess the impact of job protection deregulation using a newly constructed dataset of major reforms to employment protection legislation for regular contracts and find a statistically significant, economically 
large and robust negative effect of deregulation on the labor share. The results point to macroeconomic gains from job protection that are in line with findings in this paper.

De Loecker and Eeckhout (2017) show that an increase in average market power is partly responsible for a decrease in labor share. Deakin et al. (2014) find that worker-protective labor laws in general have no consistent relationship to unemployment but are positively correlated with labor's share of national income. Laws specifically relating to working time and employee representation are found to have beneficial effects on both efficiency and distribution thus proxied.

The decline in union density - the number of trade union members as a percentage of total employees or as a percentage of total employment - in many developed economies has often been linked to the weakening of workers' bargaining power, negatively affecting their ability to negotiate a larger share of productivity growth as labor compensation (OECD, 2009). Fichtenbaum (2011) finds that unions have a positive impact on labor's share of income and that the decline in unionization explains about 29 percent of the decline in labor's share of income. The results presented here echoes these findings especially in low-skill sectors.

This paper considers the structural factors mentioned in the literature, along with other potentially important contributors, in discussing the shifting nature of the labor share in Europe. In doing so, it is closest to Dao et al. (2017) but with a wider set of indicators and a focus on NMS instead of emerging economies. The factors mentioned here may also be correlated such as for example, changes in product market structure could also emerge independently of regulation and may reflect technological advances and globalization forces. Assessing such interdependence is beyond the scope of this study but it aims to provide a degree of robustness of the findings by correlating various indicators.

\section{MAJOR LAbOR TRENDS IN THE EU}

\section{A. Evolution of Labor Share by Skill and by Industry Sectors}

There has been a considerable erosion of labor share accrued to less-skilled workers over the period $2002-14^{1}$ as captured by the linear trend in the labor share (Figure 2). Both low-skilled jobs (factory workers and elementary occupations) and mid-skilled jobs (clerical support workers and skilled manual workers) have seen their share steadily erode across the EU. Both kinds of labor share fell by 1.7 percentage points and 1.9 percentage points respectively. Only high-skilled occupations (professionals) have experienced an increase in the labor share by 2 percentage points on average. The share accrued to low-skilled jobs has

\footnotetext{
${ }^{1}$ The latest data for skill categories available is from 2014. In contrast, sectoral data is available up to 2016.
} 
experienced the steepest decline in Greece and Malta ( 5 percentage points) as well as Croatia (4 percentage points). Only Estonia and Lithuania saw modest growth in the labor share that goes to manual workers.

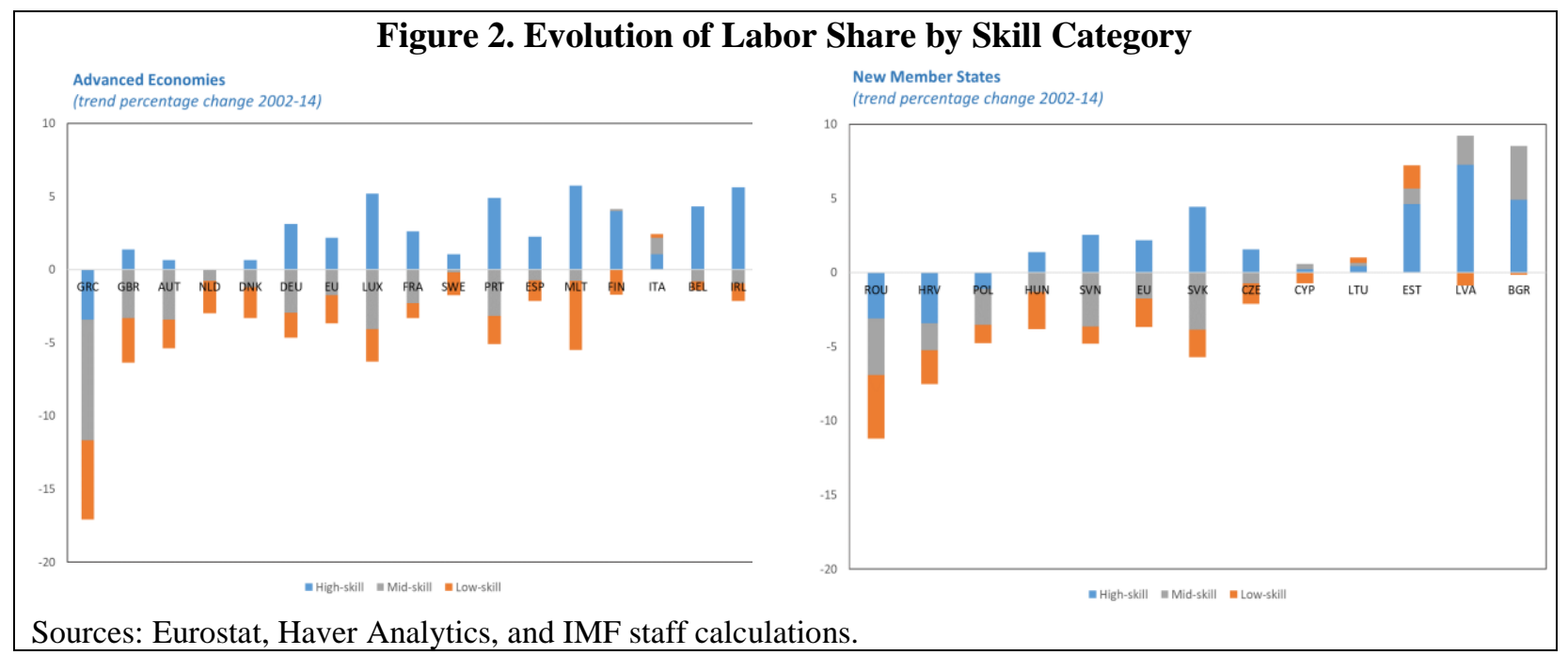

Mid-skilled workers experienced the largest erosion of compensation share that partially was absorbed by high-skilled employees. The drop was high in Austria, Luxembourg, Slovakia and Romania (4-8 percentage points) and moderate in most other EU economies. Only Finland and select NMS economies such Bulgaria, Estonia and Latvia posted relative gains. On the other hand, the majority of countries that saw a shrinking blue-collar labor share, experienced a rise in white-collar share across most economies. Croatia, Greece, Poland and Romania experienced a decline across all three categories, while Bulgaria, Estonia, Italy and Lithuania are at the other end of the spectrum. The majority of AE and some NMS economies saw a loss in low- and mid-skilled labor share that far outstripped the gain accrued to high-skilled jobs ${ }^{2}$.

Goods producing industries have lost labor share across all EU countries as captured by the linear trend in the labor share (Figure 3). Industry (that includes manufacture), manufacture and construction have experienced the largest rollback even in countries where the labor share accrued to the whole economy grew such as the Baltics, Bulgaria, Finland and Sweden. The largest drop is concentrated in manufacture whose labor share shrank by up to 3 percentage points in Finland and Malta followed by construction whose labor share declined by 2.5 percentage points in Ireland ${ }^{3}$ and Spain where in both economies the

\footnotetext{
2 The paper cautions against interpreting the sum of all skill level changes as changes in the total economy since unlike sectoral data, skill level data encompasses only full-time employed workers

${ }^{3}$ The Irish decline has been driven mainly by a sharp drop in the construction boom. Profit shifting by Irishbased multinationals is likely a secondary factor. Since the number of low-tax countries in the EU is relatively small (and covers mainly micro-states and some NMS), and given the difficulties in measuring accurately the extent of profit shifting, this factor is partially captured by country effects.
} 
recession was accompanied by a sharp reversal in the construction boom and the associated layoff of largely temporary workers. Only the Baltics and Bulgaria experienced a modest growth but starting from very low levels. Agriculture whose share in EU economies is relatively small, saw a decline in labor share in NMS with the most prominent drop in Romania and Slovakia.
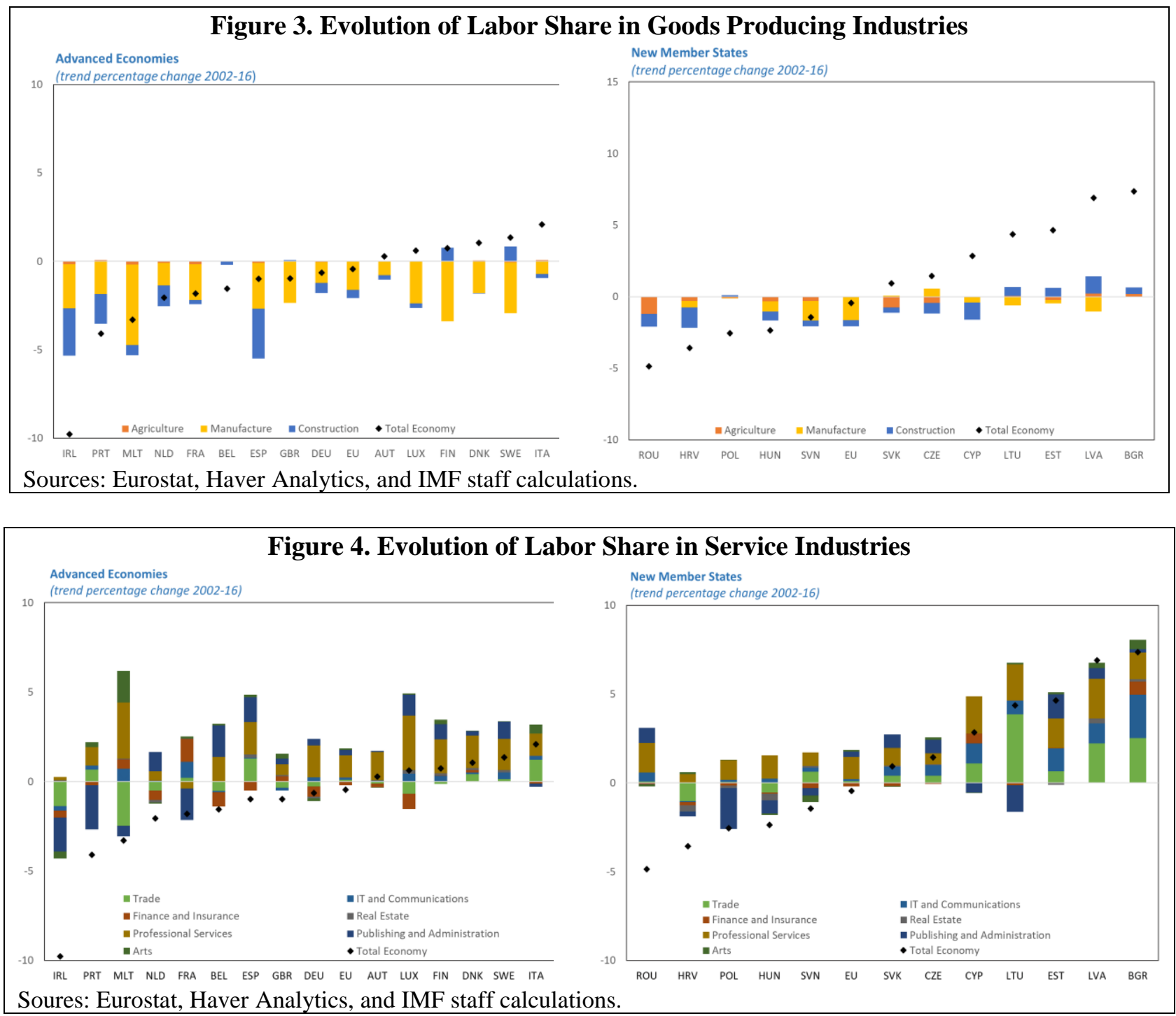

The labor share of service industries has been on the rise in most of the EU, but the gains are unevenly distributed (Figure 4). Professional services that also include information and administration have experienced the largest gain especially in countries with underdeveloped sectors such as Bulgaria, the Baltics, Cyprus, Luxembourg and Malta. Publishing and administrative services also saw an upswing except in Ireland and Portugal and in Central Europe. The trade sector lost labor share in some AE economies, notably Ireland and Malta but gained considerably in most NMS economies. Finance registered losses in outsize financial centers such as Luxembourg followed to smaller extent by Belgium, Germany and 
the Netherlands. The gains in NMS mainly accrued to previously underdeveloped professional and trade sectors and to a lesser extent IT and communication, while in AE the gains in professional and administrative industries were partially offset by a decline in trade and finance.

\section{B. Shift-Share Analysis}

In order to determine whether changes in the labor share stem from within-industry transformation or from between-industry changes, the paper performs shift-share analysis. This is an essential first step to gauge the extent to which the evolution of the labor share in one sector or skill category might have been at the expense of another. Classical trade theory posits that a shift toward capital-intensive industries in relatively capital-abundant advanced economies would result in lower labor share with the opposite phenomenon being observed in relatively labor-abundant transitional economies. The shift-share analysis can then determine whether a focus on within-category changes in labor share is indeed justified and as such is a stepping stone to the main empirical analysis.

The shift-share approach decomposes the trend changes in labor share into their withinindustry and between-industry components. The results of this exercise are shown in a square box that plots the total trend change on the horizontal axis against the within component on the vertical axis. The total change is decomposed for each yearly change as:

$$
\Delta \mathrm{LS}_{i, \mathrm{t}}=\sum_{k=1}^{n}\left(\mathrm{w}_{\mathrm{i}, \mathrm{k}, \mathrm{t}-1} \Delta L S_{\mathrm{i}, \mathrm{k}, \mathrm{t}}\right)+\sum_{k=1}^{n}\left(\Delta \mathrm{w}_{\mathrm{i}, \mathrm{k}, \mathrm{t}} \mathrm{LS}_{\mathrm{i}, \mathrm{k}, \mathrm{t}-1}\right)
$$

where the first sum is the within change and the second is the between change. $L S_{i, t}$ is the labor share of sector $k$ in country $i$ at time $t$ and $w_{i, k, t}$ is the relative weight (calculated as employment share) of the relevant sector. The annual labor share change is then summed across all years in the sample.

The shift-share analysis suggests that reallocation of factors across broad industrial categories has generally not been a significant driver of labor share trends with a few notable exceptions (Figure 7, left panel). Most countries are clustered around the 45-degree line, indicating that trend changes in labor share emerge overwhelmingly from trend changes in within-industry labor share rather than from the reallocation of factors across industries. Between-industry and between-skill reallocation explains only 17 percentage points and 22 percentage points on average respectively. In some notable outlier cases such as Ireland and Greece, it explains 25 percentage points and 29 percentage points respectively. 


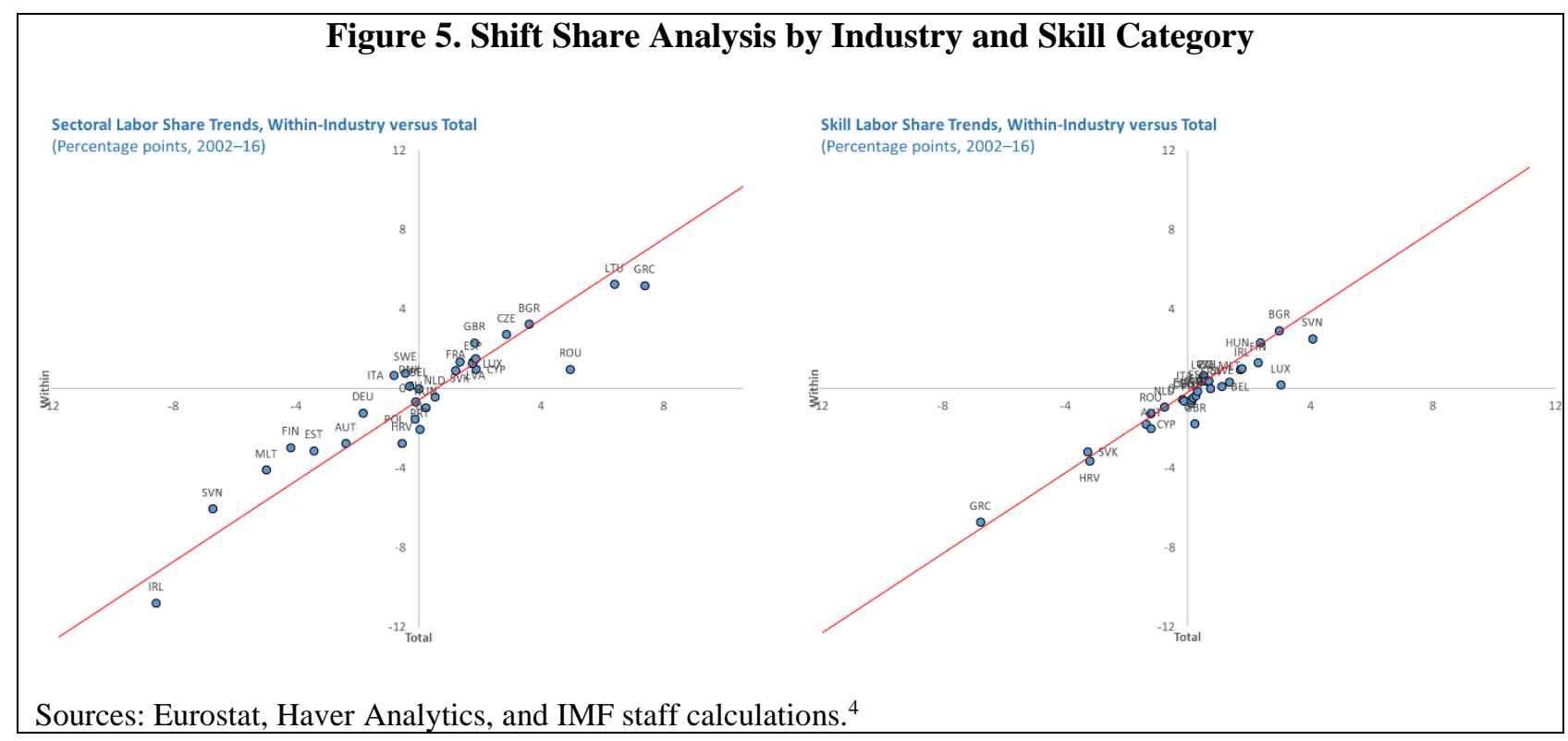

Some exceptions lying in the upper left quadrant and lower right quadrant (i.e. labor share decline is more likely due to between sector shifts rather than within sector changes) are Denmark, Hungary, Italy, Portugal, Romania and Sweden, but for most the changes are rather modest. This suggests that these mostly Advanced Economies have experienced labor reallocation from industries with relatively high labor share, most notably manufacturing, to expanding industries with lower labor share, such as service sectors. Germany also saw some between-industry shift mostly owing to the 2003-05 labor market reforms (the Hartz reforms) which reintegrated a large share of unemployed people predominantly into low labor-share sectors, leading to an increase in the relative weight of low labor share sectors. Other notable cases are Greece, Ireland and Romania which are farther from the 45-degree. Ireland lost labor share within industries which was only partly offset by between-sector reallocation. Greece is the opposite of Ireland with between-industry transfer accounting for one-third of the labor share change. Romania, on the other hand, lies further away from the 45-degree line in the upper right quadrant since its labor share gain is mainly driven by across industry changes.

Conducting the same exercise for skill categories, compares changes within skill groups with between groups flows (Figure 7, right panel). Again, the majority of countries cluster around the 45-degree line suggesting that overwhelmingly labor share losses in some skill categories are not at the expense of other categories. Those that saw notable contribution from betweensector reallocation experienced mostly modest labor share changes such as Denmark, Lithuania, Spain and the United Kingdom. Some economies place farther from the 45-degree

\footnotetext{
${ }^{4}$ Comparing the two panel sides is not advisable since the two series duffer by period coverage (2016 for sectoral vs. 2014 for skill) and the skill dataset is only available for full-time employment.
} 
line, notably below the line. Those are Luxembourg and Slovenia where considerable gains in labor share come from distributions across skill categories, notably from low-skilled to high-skilled workers. There are no countries away from the 45-degree line in the lower left quadrant implying that economies that experience labor share shrinkage did not experience redistribution across skill levels. These results are broadly in line with Dao et al. (2017) and Ciminelli, Duval and Furceri (2018).

This preliminary study suggests most labor share changes are concentrated within the industry. The drivers of these changes and their potential effect on the labor share are discussed in detail next.

\section{The Changing Landscape of Structural Factors in the EU Labor Market}

The structural factors that are expected to influence labor compensation fall broadly in three categories:

- Employment structure: self-employment share, part-time employment share and temporary employment;

- Labor market structure and policies: employment protection, unemployment benefits and unionization rate;

- Goods market structure: relative price of investment goods (automation), import penetration, domestic value-added in exports (forward link) and reexported foreign value-added (backward link);

- Cyclical controls: unemployment gap, involuntary part-time work and the EU GDP gap.

The shifting employment structure in the EU in the last two decades is characterized by a rise in part-time employment and temporary contracts (Figure 5). The share of self-employment has decreased in most advanced economies (AE) in the period 2002-16 except in France, the Netherlands and the United Kingdom. The latter two also exhibit a decline in their labor share. New member States (NMS) have a similar trend with the exception of Slovakia. Parttime employment is on the rise in all $\mathrm{AE}$ and the majority of NMS. There is a clear upward correlation between part-time employment and the labor share, and it is stronger in $\mathrm{AE}$ than in NMS.

On the other end of the spectrum is temporary employment which exhibits no correlation with labor share in AE but a clear negative relationship with labor share in NMS. This is driven mainly by the outlier cases of Latvia and Lithuania where a drop in temporary contracts coincided with a rise in labor share. At the other end of the spectrum is Poland where an influx of temporary contracts (likely from Ukraine) signaled a drop in the labor share. 


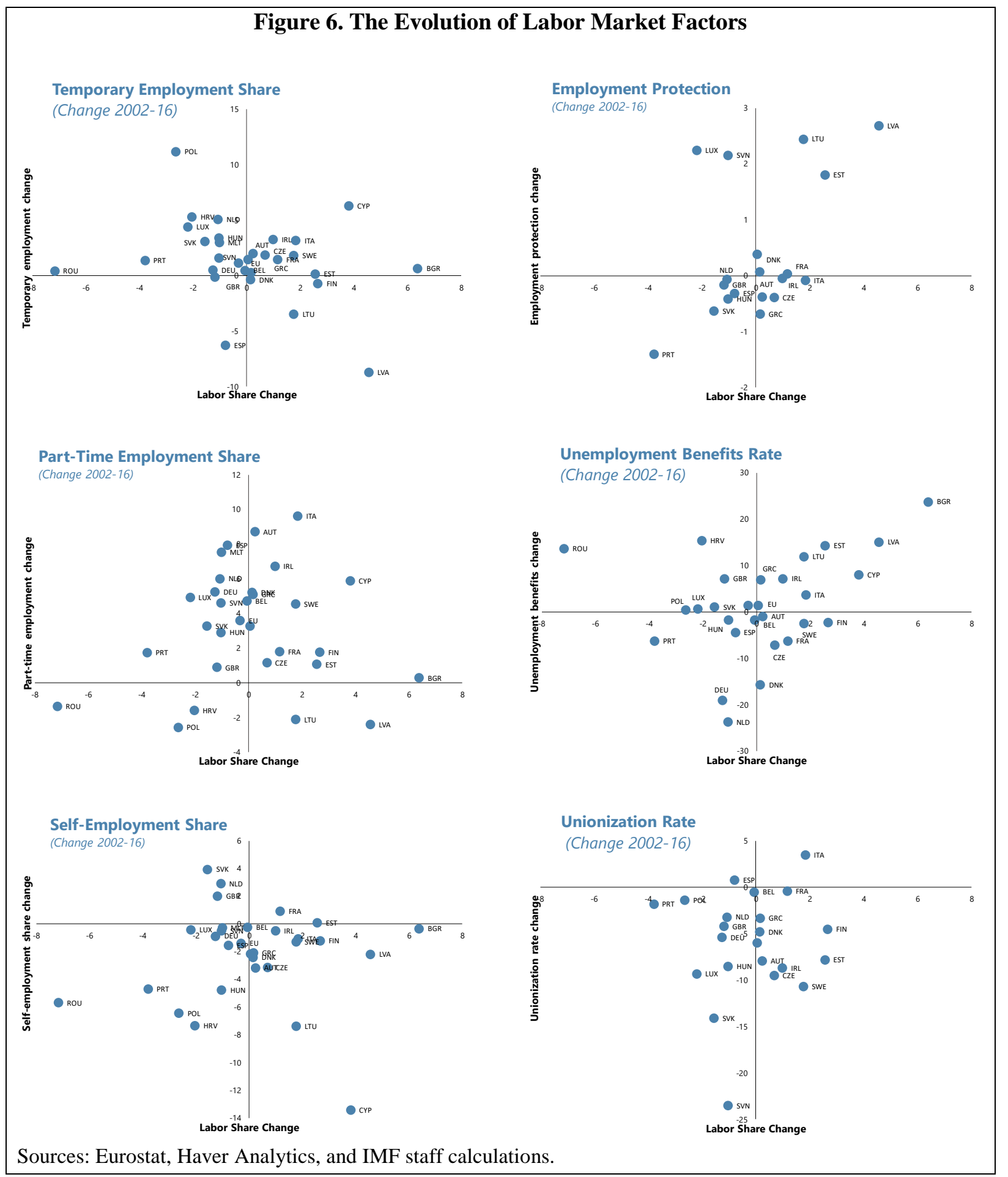

Labor market policies have been characterized with differing degrees of unionization and an expansion of unemployment benefits in NMS (Figure 5). Employment protection has remained largely unchanged in the EU except for a few notable cases. Individual and group employment protection rose in the Baltics where it accompanied labor share growth, whereas in Luxembourg and Slovenia the labor share contracted despite its expansion. Portugal is a 
notable case of employment protection rollback that coincided with labor contraction. The unionization rate dropped in all EU economies except in Italy and Spain regardless of labor compensation trends. Unemployment benefits are associated with growing labor share due to their reservation wage potential. They grew in all NMS except in some Central European states, and decreased in the majority of AE, notably in Denmark, Germany and the Netherlands.

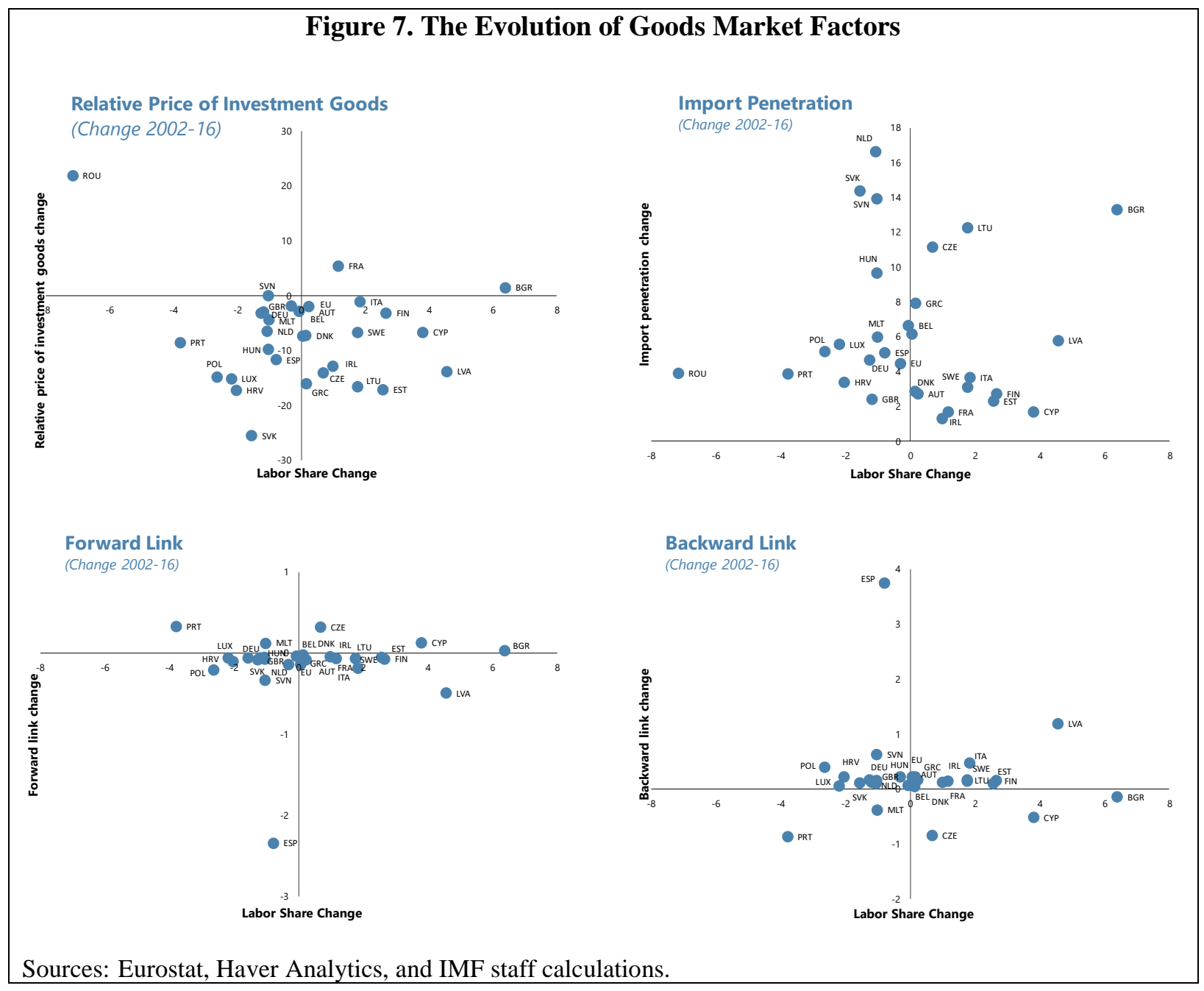

Goods market factors that influence the labor center largely around an increase of import penetration and the backward link, and a decrease in automation and the forward link (Figure 6). The relative price of investment goods (proxy for automation) has decreased across the EU but the effect on labor compensation is conflicting. It is positively correlated with labor share in AE but negatively in NMS reflecting a degree of substitutability between labor and technology in NMS that is not present in AE. Larger import penetration is strongly associated with a shrinking labor share in AE due to intense outside competition, mainly from NMS and emerging markets. The same effect is not felt in NMS where worker 
compensation tends to be lower than in AE. When it comes to GVC contribution, its correlation with the labor share is largely minimal. Most countries experienced a decline in the forward value-added and an increase in the reexported value-added regardless of developments in the labor market.

\section{Methodology}

\section{A. Data}

Empirically the labor share is usually defined as total labor compensation or labor costs over nominal GDP or nominal value-added. One contentious issue is the inclusion of income of self-employed whose labor compensation is not recorded separately in national income account (Gollin, 2002 and Bridgman, 2014). The income of self-employed is typically reported as mixed income that includes profits accrued to capital along with labor earnings. Furthermore, the definition of self-employment varies considerably from country to country. The exclusion of self-employed may be an issue in sectors with a high share of selfemployed; their income may change the labor share significantly. Krueger (1999) simply attributes two-thirds of proprietor's income to wage bill in order to calculate the labor share. The OECD, the US Bureau of Labor Statistics, and the EU KLEMS adjust labor compensation by self-employed by assuming the same average wage of self-employed and employees in the sector. This may lead to measurement errors as in different countries and sectors the wages of employees and self-employed may differ significantly (McKenzie and Brackfield, 2008; Arpaia et al., 2009; Gomme and Rupert, 2004; Timmer et al., 2007). Additionally, there is no reliable method to separate the mixed reported by self-employed into labor and non-labor earnings and this cannot be combined with employee earnings. For these reasons this paper does not include the income of self-employed in the calculation of the labor share. However, the share of self-employed, which is relatively modest in most EU economies, is included as a control in the labor share analysis.

The study covers 28 EU countries over the period 2002-2016 based on complete data availability $^{5}$. Of those Austria, Belgium, Cyprus, Denmark, Finland, France, Germany, Greece, Ireland, Italy, Luxembourg, Malta, the Netherlands, Portugal, Spain, Sweden and the United Kingdom are characterized as Advanced Economies (AE). New Member States (NMS) are Bulgaria, Croatia, Czech Republic, Estonia, Hungary, Latvia, Lithuania, Poland, Romania, Slovakia and Slovenia.

\footnotetext{
${ }^{5}$ Many structural indicators (notably some labor market policies and goods market policies) are available only starting 2002 thus limiting the overall time span.
} 
While the aggregate labor share is defined as total labor compensation relative to GDP, defining sectoral or skill labor share is less straightforward. Dao et al. (2017) define it as labor compensation (including wages and non-wage income such as benefits and bonuses) by category relative to value-added on the country level. While this approach is easier computationally and avoids the added challenge of locating value-added data by sector or skill category, it does not allow for a changing share of skill demand in total employment. In order to factor in the effect of technology on skill composition and at the same time get around data availability issues, this paper defines the labor share of a given sector/skill category as total labor compensation paid to workers in that category as a share of total GDP divided by the employment share of the given category. The only potential hazard is this approximation could lead to an overestimation of the labor share in relatively productive categories and an underestimation of the labor share in relatively unproductive sectors. Nevertheless, it is preferable to approaches that ignore the role of technology, a major structural driver. While datasets such as EU KLEMs offer shares that avoid the requirement for computations and thus potential measurement error, they have only wage shares thereby excluding non-wage income.

The labor share data comes from Eurostat and is quarterly for sectoral labor share and annual for skill labor share. Sectoral labor data continues up to 2017 but structural factors availability limit the sectoral panel to 2016. The skill level data is available up to 2014 and only for full-time employment. Data covers eleven sectors and ten professional categories that are grouped into three skill categories. The category of highly-skilled workers encompasses typical whitecollar jobs that require tertiary education of four years or more leading to a Bachelor degree or beyond, advanced training, or experience. High-skill employment positions are considered managers, professionals and technicians and associate professionals. The mid-skill category involves positions that require some specialized training, apprenticeship or education but not necessarily a Bachelor degree. These typically are clerical support workers, service and sales workers, skilled agricultural, forestry and fishery workers, and craft and related trades workers. Low-skilled jobs are blue-collar positions that require little or no training or education. These are plant and machine operators, assemblers, and other elementary occupations. The detailed variable definitions and sources are discussed in detail in the Appendix.

\section{B. Cross-Country Panel Analysis}

To assess the contribution of structural factors to the labor income share, on the focus is on the empirical relationship between trends in the labor share and the proposed labor market and goods market factors. This approach uses a cross country panel regression that relates changes in labor share to potential drivers based on influential works such as Elsby, Hobijn,

and Şahin (2013), Karabarbounis and Neiman (2014), Acemoglu and Restrepo (2016) and Dao et al. (2017). The methodology itself consists of two steps. In the first step, the effects of 
the structural indicators on the labor share are estimated. Macro fundamentals as well as cyclical factors are included to ensure a more precise capture of the structural contribution. The cross-country time series estimation recognizes that the labor share is autoregressive and includes a one-year lagged term. In the second step, the long-term effect is estimated using the coefficient of each factor times the long-term change in that factor measured as the difference between a base year, 2000, and the latest year with complete dataset, 2016. The contribution is then summed across factors and plotted diagrammatically against the change in the labor share over the same time frame.

The presented approach has been selected as the most feasible among similar specifications with robustness checks. The structural indicators have been considered both individually, together with similar indicators and as part of the complete set with no significant differences in outcomes. The presence of a lagged dependent variable does not change the results quantitatively, so an IV approach is not considered necessary. The addition of a crosscountry weighting matrix does not improve the performance of the model. Tests for cointegration have been rejected. The full panel estimation is:

$$
L S_{k, i, t}=\beta_{0}+\sum \beta_{1, m} D \Pi_{k, i, t, m}+\sum \beta_{2, n} S F_{i, t, n}+\sum \beta_{4, l} C F_{i, t, l}+\varepsilon_{k, i, t}
$$

Where:

$$
\sum \beta_{1, m} D \Pi_{k, i, t, m}=\beta_{1,1} L S_{k, i, t-4}+\beta_{1,2} \operatorname{Ugap}_{i, t-4}+\beta_{1,3} T \cdot \operatorname{Ugap}_{i, t}+\beta_{1,4} \operatorname{Rprod}_{i, t-1}
$$

Where Ugap is the unemployment gap on its own and also interacted with a time trend. Rprod is the real productivity per hour. $S F_{n}$ is the $n^{\text {th }}$ structural factor identified to potentially affect the labor share. Since the labor share adjusts slowly to changes in a specific factor, from a performance point, it is irrelevant whether the level factor is contemporaneous or lagged. The structural indicators considered are: the share of self-employed workers (the cyclical component of this indicator, the share of involuntary part-time workers, is captured by another variable with no overlap between the two), the share of part-time workers, the share of temporary workers, the relative price of investment goods (proxy for automation), the import penetration rate, the unionization rate, the unemployment benefits rate, the degree of employment protection, the forward GVC link and the backward GVC link. There are also two cyclical factors, $C F_{l}$, namely the share of involuntary part-time employment and the EU GDP gap, that help isolate cyclical fluctuations from structural changes. The dataset is quarterly for sectoral labor share and annual for skill labor share. 


\section{RESUlts}

\section{A. Expected Contribution of Structural Factors}

The long-term contribution of structural factors to the labor share is the focus of this study. The expected effects on the labor share broadly follow the literature but some countries may experience opposing effects due to still ongoing development:

- Part-time employment raises the number of employees since those employed parttime are individuals who may not otherwise be in the labor force. It would be labor share-depressing as part-time employees are paid relatively less than their full-time counterparts (those involuntarily in a part-time job due to lack of full-time employment are captured by the involuntary part-time cyclical indicator).

- Temporary contracts have a negative contribution to the labor share since they are associated with larger wage differentials and lower firing costs (Koutentakis, 2008).

- The relative price of investment goods is a proxy for automation. Technological advancement and the associated decline in the price of investment may induce firms to substitute capital for labor thus eroding the labor share both long-term and shortterm. However, in industries where the elasticity of substitution between labor and capital is below unity, such as some service industries, the opposite effect may dominate (Dao et al, 2017; WEO 2007).

- Import penetration captures the degree of trade integration and traditional theory predicts that trade integration will lead capital-abundant advanced economies to specialize in the production of capital-intensive goods, triggering resource reallocation across sectors that lowers the labor share of income (Harrison, 2002; Rodrigues and Jayadev, 2010; WEO, 2007; Elsby, Hobijn and Şahin, 2013). However, NMS countries where workers earn relatively less than their AE peers may experience the opposite effect and may gain from opening.

- The degree of unionization is expected to contribute to labor share by improving the bargaining power of labor although its effect on employment may be conflicting.

- Unemployment benefits act as a reservation wage and as such have a positive effect on the labor share. However, they may postpone return to the labor market by providing a reservation wage that could lead to the rejection of job offers. Hence, unemployment benefits would have opposite-sign effects on employment and wages, so its overall effect on the labor share is also ambiguous. Employment protection like unionization influences the labor share positively but at the expense of slower employment gains.

- Global value chain participation - measured as the sum of so-called forward and backward linkages in vertical specialization - reflects an offshoring of production in advanced economies in intermediate goods and services, particularly of labor- 
intensive tasks to emerging and developing economies. In advanced economies production becomes more capital-intensive, and a decline in labor income share ensues (Dao, et al 2017; Feenstra and Hanson, 1997; Grossman and Rossi-Hansberg, 2008). Forward GVC participation captures domestic value-added exported to a first economy that re-exports them to a third economy as embodied in other goods or services and as such ex expected to benefit the labor share. Backward GVC participation corresponds to the value-added of inputs that were imported in order to produce intermediate or final goods/services to be exported and is expected to have a negative effect on the domestic labor share.

\section{B. Sectoral Labor Share}

\section{Total Economy and Manufacturing Industries}

Economy-wide indicators show that the labor share shrank in a sizeable share of EU countries, notably some recession-hit economies (Ireland ${ }^{6}$ and Portugal) as well as some NMS countries (Croatia, Poland and Romania) but rose in other fast-growing NMS economies such as Bulgaria and the Baltics (Figure 8, Table 1). The total contribution of structural indicators explains some cases of decline but underperforms in the most severe cases (Figure 8, top left panel). By far the largest contribution comes from fluctuations in employment factors. A rise in temporary contracts is responsible for up to 3 percentage points decline in the labor share with Poland being the most prominent case. Some countries like Finland and Spain however experienced the opposite effect as the prevalence of temporary contracts decreased (mainly driven by a decline the construction sector). Selfemployment is another considerable contributor. While its role in determining the labor share is negative, it largely decreased in most EU economies, so the majority experienced a boost in the labor share from the transition from self-employment to employee work. The significance of employment developments to the evolution of the labor share may partly reflect the definition of the labor share derived as the ratio of total compensation.

Labor market policies such as employment protection and unemployment benefits were the other determinants of the labor share, but their effects were not uniform. Both affect the labor share positively and a rollback of employment protection contributed to a lower labor share in many countries, notably in Portugal and Slovakia. Unemployment benefits declined markedly in Denmark, Germany and the Netherlands but increased in Ireland and Italy. Technology and import penetration do not seem to affect the economy-wide labor share but distinct sectoral patterns persist which are discussed later in detail. The domestic value-added

\footnotetext{
${ }^{6}$ In Ireland, the headline labor share value is heavily distorted by the presence of multinationals especially in ICT and manufacturing.
} 
in exports, i.e. the forward link, has the expected positive effect on the labor share but its contribution is visible chiefly in $\mathrm{AE}$ economies.

The labor share in industry sectors (excluding construction) declined across the EU with Malta and Romania the starkest examples (Figure 8, top right panel). Structural indicators account for up to 2 percentage points labor share loss on average. The main factors that contributed to the labor share fall in industries is the rise of part-time employment supplemented in some cases by a decline in unemployment benefits. The forward link also makes a negative contribution due to the outsourcing of labor-intensive work and a specialization in capital-intensive industries. Import penetration works in the opposite direction but not enough to offset the sharp drop. Its effect is mainly concentrated in NMS economies where competition from foreign firms may boost the relatively lower domestic labor compensation levels.

In manufacturing, the labor share largely mirrored the trend across industries falling by 2 percentage points on average (Figure 8, bottom left panel). The contraction is especially pronounced in some economies such as Finland, Ireland and Malta. The factors that drove the erosion are diverse but fail to capture the starkest loss. Again, an increase in part-time employment increase and a decline in unemployment benefits coupled with a fall in unionization rates are the major drivers. The employment factors are followed by the negative contribution of the forward link in GVC participation. Globalization in the form of import penetration again has a positive effect in select economies that is only augmented in some cases by a reduction in self-employment. In Spain particularly, the decrease in employment in the manufacturing sector is closely linked to the collapse of the construction sector. The sectors where employment was destroyed most intensively were linked to household construction such as furniture, woodworks and metal structures. The overall effect of structural factors remains negative across EU countries but their ability to predict labor share contraction in severe cases is limited.

Structural indicators, coupled with cyclical factors, perform much better in the construction industry dominated by the abrupt contraction of the Spanish construction sector (Figure 8, bottom right panel). In Spain's case, beyond macroeconomic factors, a negative contribution from a rise in part-time work and cyclical factors such as involuntary part-time work contributed to the drop. Across the EU, labor share in construction experienced a similar drag mainly driven by an increase in part-time employment and a reduction in unemployment benefits. Technology as proxied by a fall in the relative price of investment goods contributes positively to the labor share likely by raising the productivity of skilled workers rather than displacing them. The notable exception is Romania where technology had the opposite effect likely due to likely prevalence of unskilled manual workers that experience replacement by technology. Self-employment contracted and to some extent offset the labor share decline. Several NMS economies and some Nordic states experienced a labor share gain. The factors 
behind this gain in Finland and Sweden are poorly captured by the model but in Bulgaria and the Baltics it was driven by cyclical effects such as a reduction in involuntary part-time work and a narrowing of the sectoral unemployment gap as well as technological improvement. 


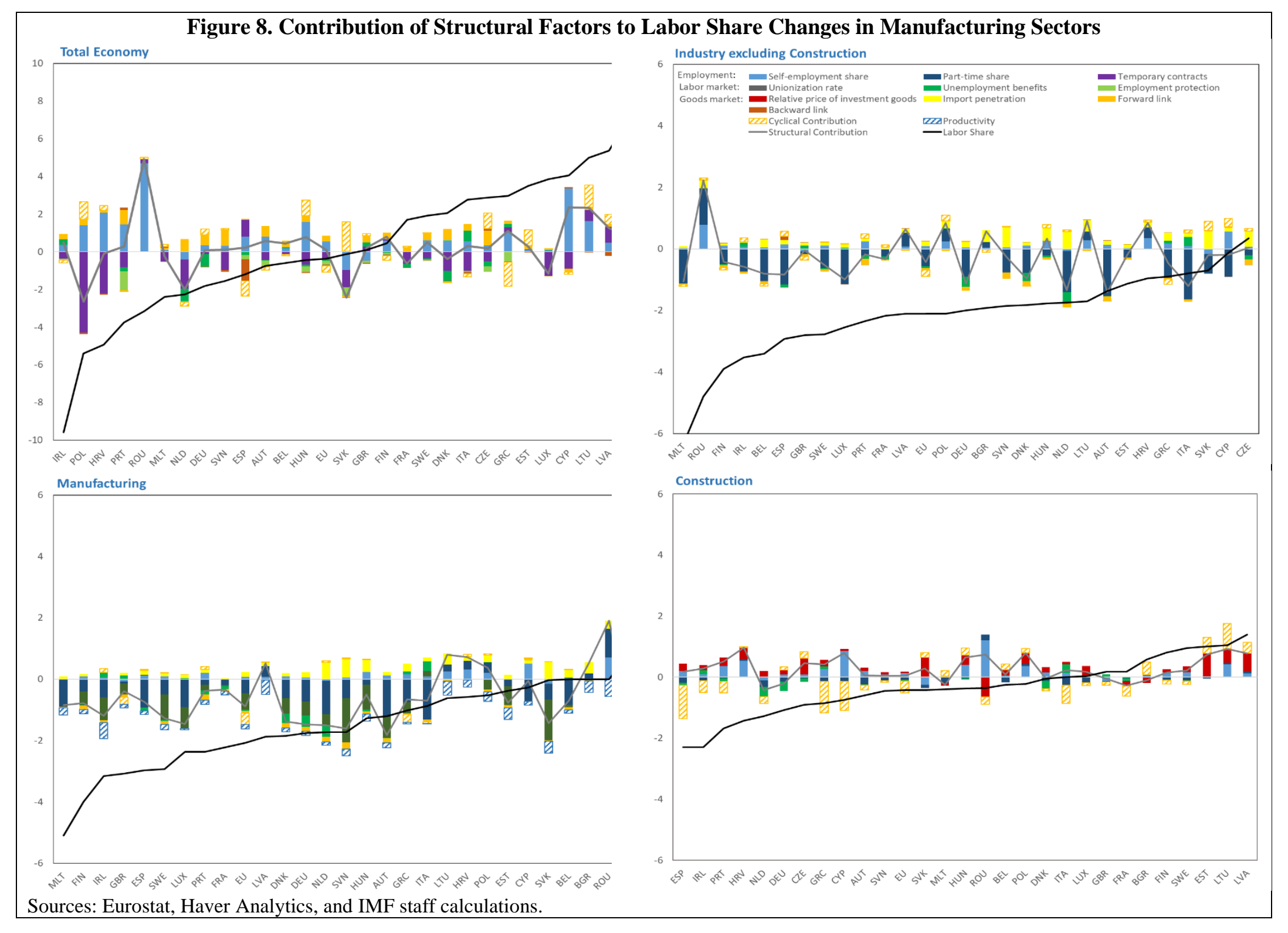




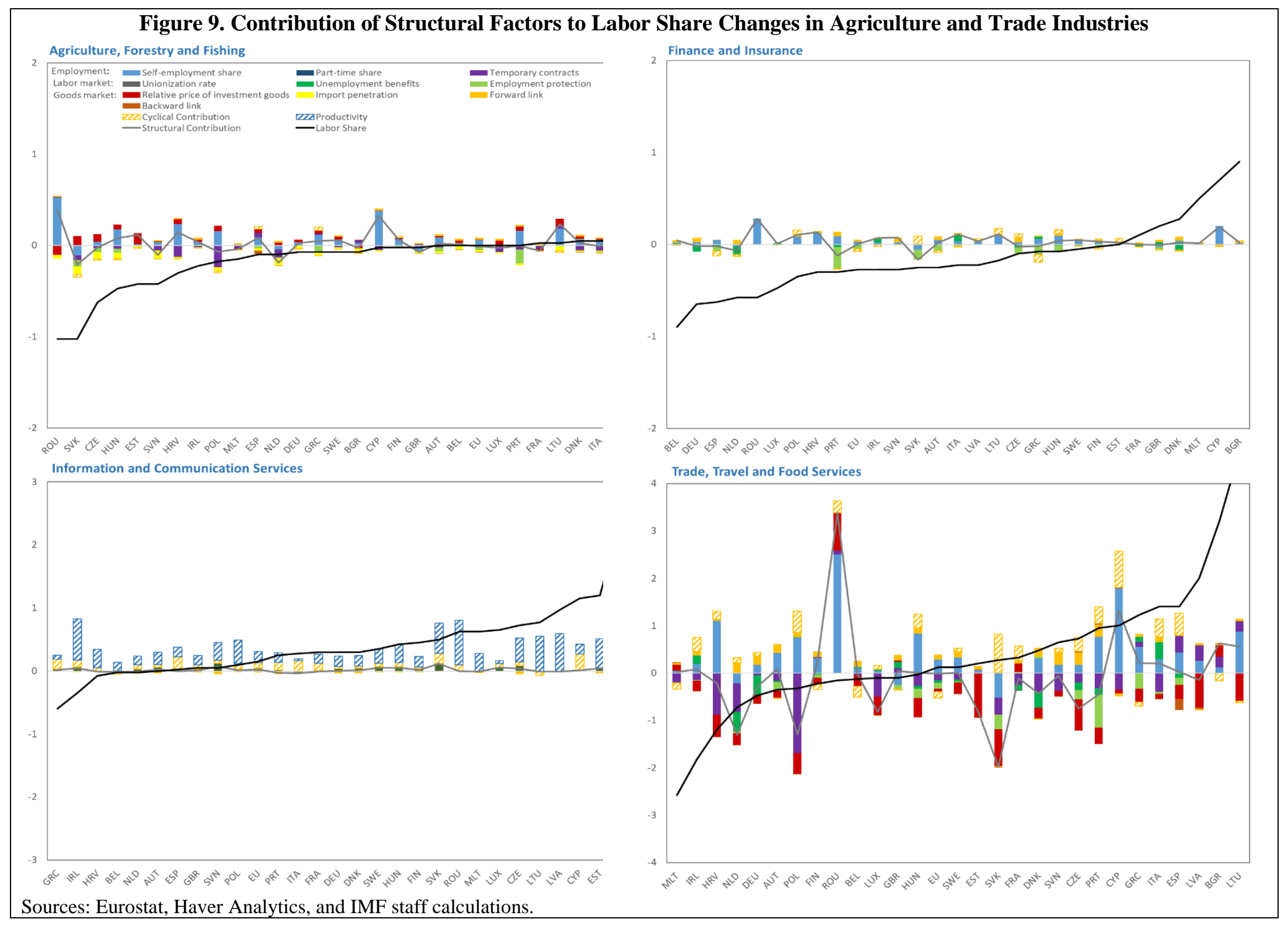




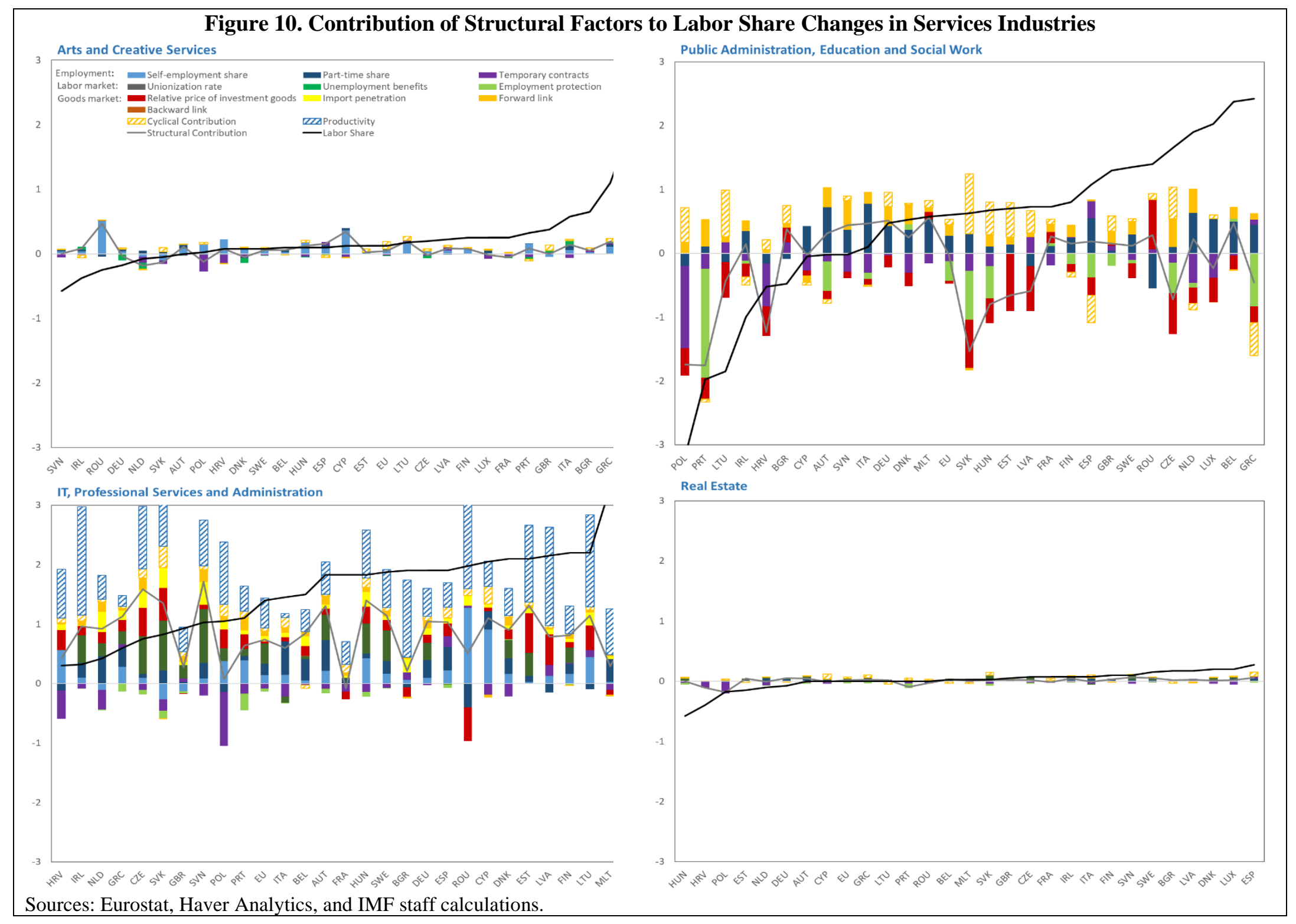




\section{Agriculture, Communication, Finance and Trade Industries}

The labor share in agriculture, communication and finance saw a modest decline, with only the trade sector experiencing sharper fluctuations across the EU (Figure 9, Table 2). The prevalence of temporary contracts in agriculture depressed the labor share in a host of countries. Import penetration and competition from low-cost non-EU producers is a close second source of labor share loss. Automation (proxied by the relative price of investment goods) augmented the labor share in agriculture with picking and sorting machines increasing the productivity of workers (Figure 9, top left panel). The effect is most prominent in NMS agricultural producers but some countries like Romania lost from technology likely due to machines replacing low skilled field workers. A decline in self-employment rates dampen the labor share decline, most notably in Cyprus and Romania. The predictive power of structural indicators particularly in Romania underperforms in explaining the largest decline despite the contraction of self-employment suggesting that other factors contributed as well.

The finance and insurance industries experienced a modest decline in a diverse set of countries ranging from small countries heavily reliant on finance such as Luxembourg to recession-affected economies such as Portugal and Spain (Figure 9, top right panel). Winners were small economies such as Bulgaria, Cyprus and Malta which rapidly deepened financialization to become a considerable overall contributor to the economy. A decline in employment protection and a rollback of unemployment benefits are the main factors behind the decline of the labor share in the infancy industry. The contraction of self-employment positively affected the labor share resulting in a small overall decline in the financial sector. GVC participation provided a small boost in the form of positive gains from the forward link.

The information and communication industry saw its labor share rise in most EU countries reflecting the white-collar nature of its employment structure (Figure 9, bottom left panel). Only recession-hit Greece and Ireland lost labor share. Few structural indicators contributed to this gain which can be attributed largely to productivity improvement followed by the positive contribution of some cyclical factors such as a narrowing of the EU GDP gap.

In contrast, the trade, travel and the food industries saw both winners and losers with the gains concentrated in NMS and Southern economies (Figure 9, bottom right panel). Technology such as online booking and trading are responsible for a large share of the labor share decline. The proliferation of temporary contracts and the erosion of labor protection are the other factors weighing on the labor share followed by a fall in unemployment benefits. On the other end of the spectrum, self-employment contributed to some labor share gain. In contrast to other sectors, technology here is labor-depressing due to the routinizable nature of work in that sector. Perhaps surprisingly, involuntary part-time work contributes positively to labor share likely reflecting a large share of part-time employed workers in the food industry 
that may be unemployed otherwise and whose earnings reflect tips in addition to hourly wages.

\section{Service Industries}

In contrast to manufacturing industries, services sectors experienced a rise in labor share to varying degrees in most EU economies (Figure 10, Table 3). The gain is most obvious in IT, professional and administrative sectors followed by public administration, education and social work. The trend is part of the "service-zation" of advanced economies and the growing labor share also reflects the education and skills premium those sectors require.

The arts and creative service industry saw its labor share grow most considerably in recession-hit economies and some NMS states (Figure 10, top left panel). The major drivers were self-employment and part-time employment reflecting the traditionally flexible employment structure in this sector in contrast to traditional employment sectors where these two factors are a drag to the labor share. Temporary work on the other hand is a drag as is the rollback of unemployment benefits. These determinants tend to underperform for the gainers suggesting that other factors are also affecting the labor share.

The public administration and education sectors saw an increase in labor share up to 3 percentage points in Belgium (likely driven by the EU administration) and Greece but also a loss of similar proportions in Lithuania, Poland and Portugal. Technology in the form of readily available online education depresses the skill premium component of the labor share in this sector. Temporary contracts and a rollback of employment protection are the other culprits largely affecting teachers and social workers. Part-time work contributed positively due to the prevalence of part-time teaching and social work opportunities. Structural factors tend to be a better predictor of labor share fluctuations, especially at the low end of the spectrum, in this sector than in others.

Perhaps the most uniform growth in labor share is in the IT, professional and administrative services where it grew between 0.5-3 percentage points across the EU (Figure 10, bottom left panel). By far the largest contributor to the labor share growth is productivity which even implies higher gains than observed in a number of NMS and recession-affected economies. As IT workers transition from self-employment to salaried work they experience gain in labor share. Unionization tends to affect the labor share negatively in this sector since skilled workers can negotiate a higher salary individually than collectively. On the other hand, technology strongly complements the skills of professional workers and tends to augment their labor share. Temporary contracts have a similar effect notably in Croatia and Poland. In contrast, the real estate sector is characterized by a stagnant labor share that saw only minor growth in countries with active construction boom such as Spain (Figure 10, bottom right panel). Some countries like Croatia and Poland where the labor share declined saw a 
rise in temporary contracts. The rest of employment and product market factors had negligible contribution that is in line with the modest fluctuations in this sector.

\begin{tabular}{|c|c|c|c|c|}
\hline \multicolumn{5}{|c|}{$\begin{array}{l}\text { Table 1. Structural Factors Contribution in Manufacturing Sectors } \\
\text { (dependent variable is Labor Share, fixed effects regression, quarterly dataset) }\end{array}$} \\
\hline & TOTAL & INDUSTRY & MANUFACTURE & CONSTRUCT \\
\hline \multirow[t]{2}{*}{ Labor Share, 1-Year Lag } & $0.798 * * *$ & $0.838 * * *$ & $0.847 * * *$ & $0.728 * * *$ \\
\hline & $(0.037)$ & $(0.017)$ & $(0.020)$ & $(0.059)$ \\
\hline \multirow[t]{2}{*}{ Unemployment Gap, 1-Year Lag } & $-0.204 * * *$ & 0.019 & $0.032 * *$ & $-0.086 * * *$ \\
\hline & $(0.042)$ & $(0.013)$ & $(0.012)$ & $(0.022)$ \\
\hline \multirow[t]{2}{*}{ Unemployment Gap X Time } & -0.002 & $-0.002 * * *$ & $-0.003 * * *$ & -0.001 \\
\hline & $(0.004)$ & $(0.001)$ & $(0.001)$ & $(0.002)$ \\
\hline \multirow[t]{2}{*}{ Real Productivity, 1-Year Lag } & -0.026 & -0.009 & $-0.008 *$ & -0.001 \\
\hline & $(0.027)$ & $(0.005)$ & $(0.004)$ & $(0.007)$ \\
\hline \multirow[t]{2}{*}{ Self-Employment Share } & $-0.234 * *$ & $-0.039 * *$ & $-0.035 * *$ & $-0.060 * *$ \\
\hline & $(0.105)$ & $(0.018)$ & $(0.015)$ & $(0.022)$ \\
\hline \multirow[t]{2}{*}{ Involuntary Part-Time Work } & 0.014 & $0.006^{*}$ & 0.004 & $-0.019 * *$ \\
\hline & $(0.014)$ & $(0.004)$ & $(0.003)$ & $(0.007)$ \\
\hline \multirow[t]{2}{*}{ Part-Time Share } & 0.122 & $-0.159 * *$ & $-0.127 * *$ & $-0.025^{*}$ \\
\hline & $(0.122)$ & $(0.057)$ & $(0.051)$ & $(0.014)$ \\
\hline \multirow[t]{2}{*}{ Temporary Contracts } & $-0.250 *$ & 0.010 & 0.009 & 0.004 \\
\hline & $(0.139)$ & $(0.011)$ & $(0.010)$ & $(0.019)$ \\
\hline \multirow[t]{2}{*}{ Relative Price of Investment Goods } & -0.035 & 0.003 & -0.001 & $0.025 * *$ \\
\hline & $(0.044)$ & $(0.007)$ & $(0.007)$ & $(0.010)$ \\
\hline \multirow[t]{2}{*}{ Import Penetration } & 0.107 & $0.033 * * *$ & $0.032 * * *$ & 0.011 \\
\hline & $(0.070)$ & $(0.010)$ & $(0.009)$ & $(0.010)$ \\
\hline \multirow[t]{2}{*}{ EU GDP Gap } & $-0.084 * *$ & 0.010 & 0.012 & 0.001 \\
\hline & $(0.040)$ & $(0.009)$ & $(0.008)$ & $(0.007)$ \\
\hline \multirow[t]{2}{*}{ Unionization Rate } & -0.040 & -0.012 & $0.071 * * *$ & -0.022 \\
\hline & -0.055 & $(0.010)$ & $(0.023)$ & $(0.015)$ \\
\hline \multirow[t]{2}{*}{ Unemployment Benefits } & $0.034 * *$ & $0.017 *$ & $0.019^{*}$ & $0.016^{* *}$ \\
\hline & $(0.013)$ & $(0.009)$ & $(0.009)$ & $(0.006)$ \\
\hline \multirow[t]{2}{*}{ Employment Protection } & $0.729 * *$ & 0.129 & 0.078 & -0.065 \\
\hline & $(0.319)$ & $(0.127)$ & $(0.118)$ & $(0.105)$ \\
\hline \multirow[t]{2}{*}{ Forward Link } & $1.837 * *$ & $-0.421^{*}$ & $-0.474 * *$ & 0.191 \\
\hline & $(0.762)$ & $(0.205)$ & $(0.179)$ & $(0.173)$ \\
\hline \multirow[t]{2}{*}{ Backward Link } & $-0.064 *$ & $0.007 *$ & 0.002 & 0.004 \\
\hline & $(0.032)$ & $(0.003)$ & $(0.003)$ & $(0.010)$ \\
\hline Constant & 3.608 & $3.521 * * *$ & $3.543 * * *$ & -1.038 \\
\hline Observations & $(5.455)$ & $(0.836)$ & $(0.655)$ & $(1.448)$ \\
\hline R-squared & 956 & 956 & 955 & 955 \\
\hline Number of countries & 27 & 27 & 27 & 27 \\
\hline \multicolumn{5}{|c|}{ Note: Significance levels denoted as $* * * \mathrm{p}<0.01, * * \mathrm{p}<0.05, * \mathrm{p}<0.1$} \\
\hline
\end{tabular}




\begin{tabular}{|c|c|c|c|c|}
\hline \multicolumn{5}{|c|}{$\begin{array}{l}\text { Table 2. Structural Factors Contribution in Agriculture and Trade Sectors } \\
\text { (dependent variable is Labor Share, fixed effects regression, quarterly dataset) }\end{array}$} \\
\hline & AGRICULTURE & COMMUNICATIONS & FINANCE & TRAD \\
\hline \multirow[t]{2}{*}{ Labor Share, 1-Year Lag } & $0.684 * * *$ & $0.586 * * *$ & $0.751 * * *$ & $0.712 *$ \\
\hline & $(0.035)$ & $(0.047)$ & $(0.031)$ & $(0.04$ \\
\hline \multirow[t]{2}{*}{ Unemployment Gap, 1-Year Lag } & $0.005 * * *$ & -0.006 & $-0.012 * *$ & -0.030 \\
\hline & $(0.001)$ & $(0.006)$ & $(0.005)$ & $(0.01$ \\
\hline \multirow[t]{2}{*}{ Unemployment Gap X Time } & -0.001 & 0.001 & 0.001 & -0.002 \\
\hline & $(0.000)$ & $(0.000)$ & $(0.000)$ & $(0.00$ \\
\hline \multirow[t]{2}{*}{ Real Productivity, 1-Year Lag } & -0.001 & $0.010 * *$ & 0.006 & -0.00 \\
\hline & $(0.001)$ & $(0.004)$ & $(0.004)$ & $(0.00)$ \\
\hline \multirow[t]{2}{*}{ Self-Employment Share } & $-0.026 * * *$ & 0.004 & $-0.014 * * *$ & -0.124 \\
\hline & $(0.008)$ & $(0.010)$ & $(0.004)$ & $(0.019$ \\
\hline \multirow[t]{2}{*}{ Involuntary Part-Time Work } & 0.000 & $0.005 * * *$ & -0.002 & $0.017 *$ \\
\hline & $(0.001)$ & $(0.001)$ & $(0.003)$ & $(0.00$ \\
\hline \multirow[t]{2}{*}{ Part-Time Share } & -0.000 & -0.011 & 0.004 & 0.01 \\
\hline & $(0.002)$ & $(0.007)$ & $(0.008)$ & $(0.01$ \\
\hline \multirow[t]{2}{*}{ Temporary Contracts } & $-0.014 * * *$ & 0.001 & -0.004 & -0.098 \\
\hline & $(0.005)$ & $(0.006)$ & $(0.006)$ & $(0.029)$ \\
\hline \multirow[t]{2}{*}{ Relative Price of Investment Goods } & $0.004 * *$ & 0.001 & -0.000 & -0.031 \\
\hline & $(0.002)$ & $(0.005)$ & $(0.003)$ & $(0.012)$ \\
\hline \multirow[t]{2}{*}{ Import Penetration } & $-0.005 * *$ & 0.000 & -0.001 & 0.00 \\
\hline & $(0.002)$ & $(0.003)$ & $(0.006)$ & $(0.01$ \\
\hline \multirow[t]{2}{*}{ EU GDP Gap } & $-0.004 * * *$ & $-0.032 * * *$ & 0.007 & -0.028 \\
\hline & $(0.001)$ & $(0.006)$ & $(0.006)$ & $(0.01$ \\
\hline \multirow[t]{2}{*}{ Unionization Rate } & -0.002 & $-0.006^{*}$ & 0.011 & -0.00 \\
\hline & $(0.002)$ & $(0.003)$ & $(0.007)$ & $(0.012)$ \\
\hline \multirow[t]{2}{*}{ Unemployment Benefits } & 0.001 & 0.000 & $0.004 *$ & $0.021 *$ \\
\hline & $(0.000)$ & $(0.002)$ & $(0.002)$ & $(0.00$ \\
\hline \multirow[t]{2}{*}{ Employment Protection } & $0.110 * *$ & 0.078 & $0.167 *$ & $0.495 *$ \\
\hline & $(0.049)$ & $(0.069)$ & $(0.092)$ & $(0.08$ \\
\hline \multirow[t]{2}{*}{ Forward Link } & -0.007 & $-0.115^{* *}$ & $0.125^{*}$ & $0.600^{\prime}$ \\
\hline & $(0.036)$ & $(0.054)$ & $(0.070)$ & $(0.27$ \\
\hline \multirow[t]{2}{*}{ Backward Link } & $-0.002 *$ & -0.000 & 0.002 & -0.013 \\
\hline & $(0.001)$ & $(0.002)$ & $(0.002)$ & $(0.00$ \\
\hline Constant & $1.035^{*}$ & 0.199 & -0.622 & 2.37 \\
\hline Observations & $(0.567)$ & $(0.987)$ & $(0.752)$ & $(1.48$ \\
\hline R-squared & 956 & 956 & 956 & 956 \\
\hline Number of countries & 27 & 27 & 27 & 27 \\
\hline
\end{tabular}




\begin{tabular}{|c|c|c|c|c|}
\hline \multicolumn{5}{|c|}{$\begin{array}{l}\text { Table 3. Structural Factors Contribution in Service Sectors } \\
\text { (dependent variable is Labor Share, fixed effects regression, quarterly dataset) }\end{array}$} \\
\hline & ARTS & PROFESSIONAL & PUBLISHING & REAL ESTAT \\
\hline \multirow[t]{2}{*}{ Labor Share, 1-Year Lag } & $0.605^{* * *}$ & $0.750 * * *$ & $0.718 * * *$ & $0.561 * * *$ \\
\hline & $(0.043)$ & $(0.056)$ & $(0.043)$ & $(0.074)$ \\
\hline \multirow{2}{*}{ Unemployment Gap, 1-Year Lag } & $-0.018 * * *$ & $-0.023 * * *$ & $-0.137 * * *$ & -0.003 \\
\hline & $(0.003)$ & $(0.004)$ & $(0.020)$ & $(0.002)$ \\
\hline \multirow[t]{2}{*}{ Unemployment Gap X Time } & $0.001 * * *$ & 0.000 & $0.002 *$ & 0.000 \\
\hline & $(0.000)$ & $(0.000)$ & $(0.001)$ & $(0.000)$ \\
\hline \multirow[t]{2}{*}{ Real Productivity, 1-Year Lag } & -0.004 & $0.028 * * *$ & -0.017 & -0.000 \\
\hline & $(0.002)$ & $(0.006)$ & $(0.011)$ & $(0.001)$ \\
\hline \multirow[t]{2}{*}{ Self-Employment Share } & $-0.025 * *$ & $-0.063 * * *$ & 0.013 & -0.001 \\
\hline & $(0.005)$ & $(0.014)$ & $(0.034)$ & $(0.003)$ \\
\hline \multirow[t]{2}{*}{ Involuntary Part-Time Work } & 0.000 & $0.006 * *$ & -0.003 & $0.002 * *$ \\
\hline & $(0.001)$ & $(0.002)$ & $(0.008)$ & $(0.001)$ \\
\hline \multirow[t]{2}{*}{ Part-Time Share } & $0.006 *$ & $0.054 * * *$ & $0.075 * *$ & $0.005^{*}$ \\
\hline & $(0.003)$ & $(0.017)$ & $(0.027)$ & $(0.003)$ \\
\hline \multirow[t]{2}{*}{ Temporary Contracts } & $-0.009 * *$ & $-0.053 * *$ & $-0.075^{*}$ & $-0.011 * * *$ \\
\hline & $(0.004)$ & $(0.022)$ & $(0.037)$ & $(0.003)$ \\
\hline \multirow[t]{2}{*}{ Relative Price of Investment Goods } & 0.001 & $0.022 * *$ & $-0.030 * *$ & 0.000 \\
\hline & $(0.001)$ & $(0.010)$ & $(0.014)$ & $(0.001)$ \\
\hline \multirow[t]{2}{*}{ Import Penetration } & 0.002 & $0.020^{*}$ & 0.003 & -0.001 \\
\hline & $(0.002)$ & $(0.010)$ & $(0.040)$ & $(0.001)$ \\
\hline \multirow[t]{2}{*}{ EU GDP Gap } & $-0.015^{* *}$ & $-0.039 * * *$ & $-0.083 * * *$ & 0.001 \\
\hline & $(0.002)$ & $(0.012)$ & $(0.020)$ & $(0.001)$ \\
\hline \multirow[t]{2}{*}{ Unionization Rate } & -0.000 & -0.013 & 0.010 & $-0.004 * *$ \\
\hline & $(0.003)$ & $(0.012)$ & $(0.021)$ & $(0.001)$ \\
\hline \multirow[t]{2}{*}{ Unemployment Benefits } & $0.005 * *$ & 0.002 & 0.010 & 0.001 \\
\hline & $(0.001)$ & $(0.004)$ & $(0.008)$ & $(0.000)$ \\
\hline \multirow[t]{2}{*}{ Employment Protection } & 0.003 & $0.199 * *$ & $1.220 * * *$ & $0.056^{* *}$ \\
\hline & $(0.032)$ & $(0.091)$ & $(0.398)$ & $(0.023)$ \\
\hline \multirow[t]{2}{*}{ Forward Link } & $0.605 * * *$ & $0.459 * * *$ & $1.019 * *$ & 0.012 \\
\hline & $(0.057)$ & $(0.158)$ & $(0.413)$ & $(0.049)$ \\
\hline \multirow[t]{2}{*}{ Backward Link } & -0.002 & 0.009 & 0.014 & -0.000 \\
\hline & $(0.003)$ & $(0.006)$ & $(0.019)$ & $(0.001)$ \\
\hline Constant & 0.239 & -1.358 & 2.523 & 0.164 \\
\hline Observations & $(0.397)$ & $(1.045)$ & $(2.755)$ & $(0.163)$ \\
\hline R-squared & 956 & 956 & 956 & 956 \\
\hline Number of countries & 27 & 27 & 27 & 27 \\
\hline
\end{tabular}

\section{Skill Labor Share}

\section{Highly-Skilled Workers}

The category of highly-skilled workers encompasses typical white-collar jobs that require tertiary education of four years or more leading to a Bachelor degree or beyond, advanced 
training, or experience. This study considers high skill employment positions that include managers, professionals and technicians and associate professionals. The labor share accruing to high-skill workers grew in most EU economies with the highest growth concentrated in recession-hit economies (with the exception of Greece) and select NMS countries (notably Bulgaria and Hungary) (Figure 11, top left panel). Moderate gains in the range of $1-3$ percentage points accrued to AE economies while $4-6$ percentage points increase was registered in countries that either started from low compensation levels or experienced sluggish labor share during contractions.

To a large extent, this increase has been driven by productivity gains which added 1 percentage point on average aided by cyclical factors such as the EU GDP gap that drives convergence (Table 4). Structural factors contribute 2 percentage points on average. Parttime share, normally a drag on labor share, here raises the share accrued to highly skilled workers reflecting the employment flexibility of many white-collar professions such as law and IT. Import penetration depresses the labor share by inviting competition from lower-paid professionals form outside the EU. The model does not capture the full picture of the drivers of labor share expansion in countries that made the most impressive gains.

\section{Mid-Skilled Workers}

The mid-skill category involves positions that require some specialized training, apprenticeship or education but not necessarily a Bachelor degree. These typically are clerical support workers, service and sales workers, skilled agricultural, forestry and fishery workers, and craft and related trades workers. The labor share of mid-skilled workers decreased almost everywhere except in select NMS countries (Figure 11, top right panel). The steepest decline by far was in Greece (8 percentage points) followed by Austria, Croatia, Cyprus and Luxembourg (4 percentage points).

Structural indicators explain a small part of this loss far from the steepest decline (Table 4). Productivity does not appear to be a factor in the labor share loss while cyclical indicators have a role only in economies such as Greece where unemployment is a considerable drag. The erosion of employment protection and a rise in temporary contracts are the main employment factors contributing to lower the labor share.

Skill hollowing effects from GVC integration (captured by the negative contribution of the forward link) further dampen the labor share. These effects are partly offset by the positive role of trade openness. Overall, structural factors, coupled with fundamentals and cyclical factors, explain only labor share losses up to 2 percentage points suggesting that broader shifts in the labor share are present. 


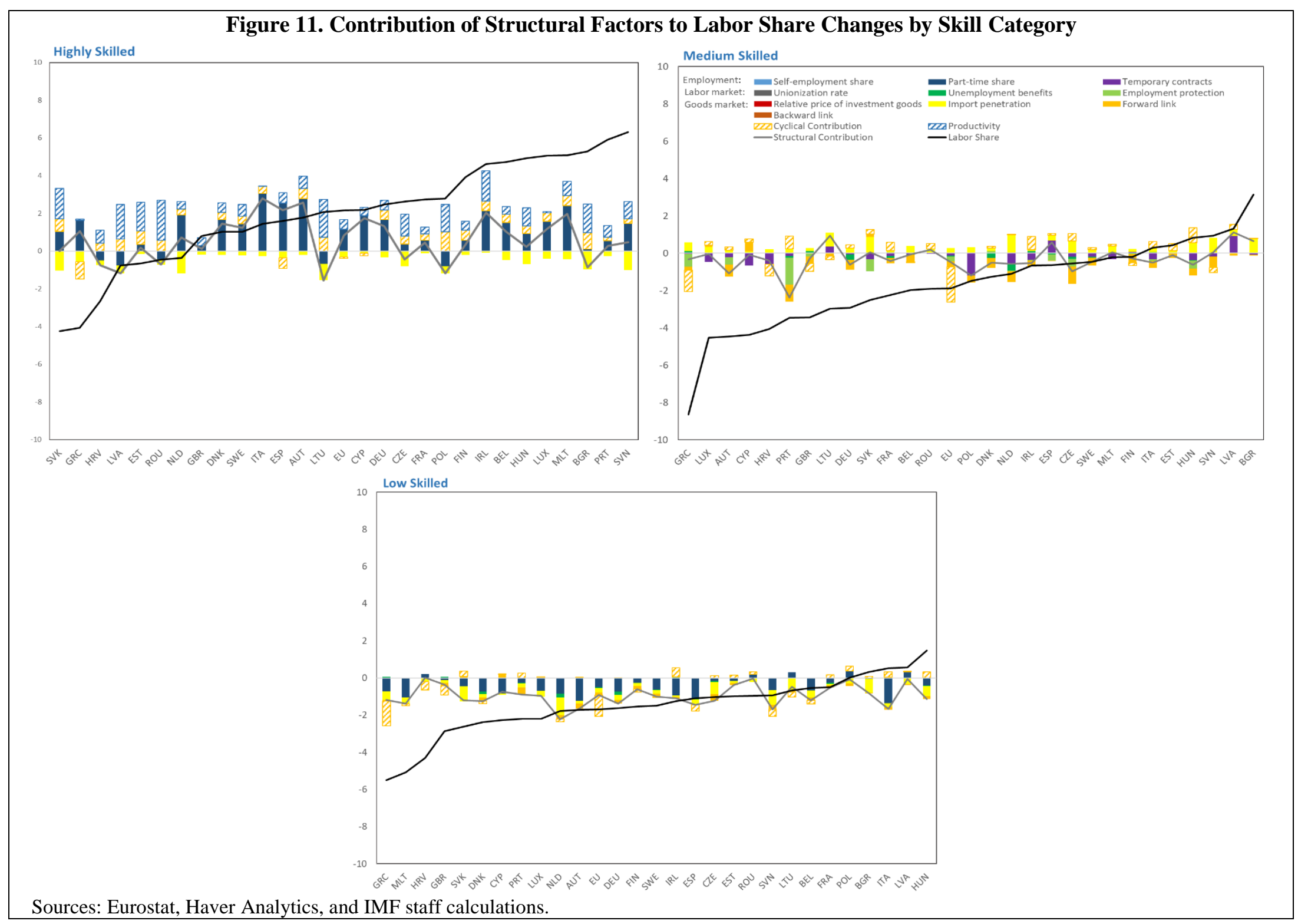




\begin{tabular}{|c|c|c|c|}
\hline $\begin{array}{l}\text { Table 4. Struct } \\
\text { (dependent variable is }\end{array}$ & $\begin{array}{l}\text { Factors Co } \\
\text { or Share, fixec }\end{array}$ & $\begin{array}{l}\text { ution by } \mathbf{S k} \\
\text { ts regression, }\end{array}$ & $\begin{array}{l}\text { tegory } \\
\text { erly dataset) }\end{array}$ \\
\hline & LOW SKILL & MID SKILL & HIGH SKILL \\
\hline Labor Share, 1-Year Lag & $0.445 * * *$ & $0.631 * * *$ & $0.705 * * *$ \\
\hline & $(0.088)$ & $(0.078)$ & $(0.066)$ \\
\hline Unemployment Gap, 1-Year Lag & $-0.118^{*}$ & $0.175^{* *}$ & -0.004 \\
\hline & $(0.067)$ & $(0.066)$ & $(0.020)$ \\
\hline Unemployment Gap X Time & 0.006 & $-0.018 * * *$ & $-0.008 * *$ \\
\hline & $(0.005)$ & $(0.004)$ & $(0.003)$ \\
\hline Real Productivity, 1-Year Lag & $0.049 *$ & -0.024 & 0.008 \\
\hline & $(0.028)$ & $(0.020)$ & $(0.011)$ \\
\hline Self-Employment Share & -0.021 & -0.018 & 0.020 \\
\hline & $(0.102)$ & $(0.061)$ & $(0.038)$ \\
\hline Involuntary Part-Time Work & 0.004 & $0.019^{*}$ & $0.018 * *$ \\
\hline & $(0.019)$ & $(0.011)$ & $(0.008)$ \\
\hline Part-Time Share & $0.318 * * *$ & -0.024 & $-0.140 * *$ \\
\hline & $(0.104)$ & $(0.035)$ & $(0.064)$ \\
\hline Temporary Contracts & -0.037 & $-0.106 * *$ & -0.012 \\
\hline & $(0.063)$ & $(0.045)$ & $(0.030)$ \\
\hline Relative Price of Investment Goods & 0.068 & 0.020 & 0.018 \\
\hline & $(0.046)$ & $(0.016)$ & $(0.011)$ \\
\hline Import Penetration & $-0.072 *$ & $0.059 * * *$ & $-0.057 *$ \\
\hline & $(0.038)$ & $(0.019)$ & $(0.031)$ \\
\hline EU GDP Gap & $-0.285 * * *$ & $-0.098 * * *$ & $-0.026 * *$ \\
\hline & $(0.054)$ & $(0.028)$ & $(0.013)$ \\
\hline Unionization Rate & -0.002 & -0.025 & -0.008 \\
\hline & $(0.042)$ & (0.018) & $(0.020)$ \\
\hline Unemployment Benefits & 0.013 & $0.016^{* * *}$ & $0.009 * *$ \\
\hline & $(0.017)$ & $(0.006)$ & $(0.004)$ \\
\hline Employment Protection & -0.159 & $1.025^{* *}$ & -0.090 \\
\hline & $(0.633)$ & $(0.379)$ & $(0.126)$ \\
\hline Forward Link & 0.240 & $-2.316^{*}$ & $-0.916 * *$ \\
\hline & $(1.063)$ & (1.199) & $(0.338)$ \\
\hline Backward Link & -0.007 & -0.014 & -0.007 \\
\hline & $(0.018)$ & $(0.011)$ & $(0.013)$ \\
\hline Constant & -1.159 & $9.048 *$ & 1.939 \\
\hline & (7.006) & $(4.735)$ & $(2.629)$ \\
\hline Observations & 211 & 211 & 211 \\
\hline R-Squared & 0.620 & 0.712 & 0.824 \\
\hline Number of countries & 21 & 21 & 21 \\
\hline Note: Significance levels denoted as $* * *$ & $01, * * \mathrm{p}<0.0$ & 0.1. & \\
\hline
\end{tabular}

\section{Low-Skilled Workers}

Low-skilled jobs are blue-collar positions that require little or no training or education. These include plant and machine operators, assemblers, and other elementary occupations. The performance of labor share in low-skilled occupations mirrors that for mid-skilled positions 
(Figure 11, bottom panel). Most countries experienced various degrees of erosion except in select NMS economies. The loss ranged from 0.5 in France to 6 percentage points in Greece.

Unlike, mid-skilled workers, low-skilled employees saw their labor share shrink largely due to an increase in part-time employment (Table 4). This effect is augmented by the rollback of unemployment benefits. Import penetration which boosted the labor share of mid-skilled workers had the opposite effect on low-skilled workers. Structural factors account for up to 3 percentage points of the labor share loss. Both low-skilled and mid-skilled workers did not experience the same productivity gains that boosted the labor share of high-skilled employees.

\section{SUMMARY AND POLICY IMPLICATIONS}

This paper documents the stagnating or downward trend in the labor share across the EU noting the considerable heterogeneity across countries, sectors, and skill groups. In most economies, the decline has been driven by within-sector effects, rather than labor reallocation among sectors. This erosion is heavily tilted toward low-skilled and mid-skilled workers who saw their labor share decrease by up to 5 and 8 percentage points respectively while high-skilled professionals were the only ones who gained 2 percentage points of labor share on average. Labor-intensive goods producing industries employing primarily low-skilled workers also lost about 2 percentage points of labor share while human capital-intensive service sectors gained a similar amount.

The empirical analysis points to the dominant role of various employment factors and labor market policies in this trend. Employment factors such as a rise in part-time employment and in temporary contracts were among the main contributors to lower labor share in almost all countries and sectors. The fall in self-employment dampened the effect to some extent. By far the largest erosion is concentrated in manufacture stemming from the rise of part-time employment supplemented by labor market effects such as a decline in unionization rates. These factors along with the steady erosion of unemployment benefits and of employment protection added a 1 percentage point drag on average to the labor share in construction, finance, manufacture, public administration and trade and in countries with shrinking labor share such as Germany and the Netherlands.

In contrast to manufacturing industries, service sectors experienced a rise in labor share in most EU economies. The trend is part of the "service-zation" of advanced economies and the growing labor share also reflects the education and skills premium those sectors require. The skill premium and employment flexibility in those sectors ensure that self-employment and part-time employment contribute to the labor share growth and are only modestly constrained by technological advancement. Technology is not the main villain in the labor share stagnation. Automation depressed the labor share only in sectors such as trade and travel where jobs are relatively easy to routinize but helped raise productivity of specialized workers in diverse fields such as agriculture, construction and professional services. Globalization in the form of import 
penetration has a positive effect on the labor share on the manufacturing sector in some NMS economies where relatively low domestic wages compete with higher incomes in AE. In agriculture, NMS countries experience the opposite effect from globalization where their labor share feels downward pressure from even lower income non-EU economies.

The gains in service sectors overlap with those made by high-skilled professionals and their labor share grew in most EU economies with the highest growth concentrated in recession-hit economies and NMS countries. This increase has been driven mainly by productivity ( 1 percentage point) and followed by flexible work environments ( 0.5 percentage points). At the other end of the spectrum are low- and mid-skilled workers whose labor share shrank primarily owing to globalization aided by the erosion of unemployment benefits and employment protection. Their productivity also remained stagnant causing them to further fall behind their more educated peers.

The design of specific policy responses may have to depend on country circumstances, given the sizable differences in levels of development, economic deepening and demographic characteristics. In general, policies that help workers develop complementarities to technology to avoid being displaced would be welcome across the country cohort and may be useful long-term investment. On-the-job training and lifelong education could offset at least partially the disruptions caused by technological progress and global integration. Upgrading social security nets such as the provision of employment protection and unemployment benefits may need to be reformed in view of the shifting nature of employment formats. Extending coverage to part-time and self-employed workers while facilitating job transition could preserve further labor share erosion. A particular challenge facing NMS is to accommodate economic deepening and GVC integration while avoiding lock-in in low value-added low-skilled segments of the chain and preserving technological transfer.

The declining labor share in EU need not be a doomsday scenario but rather be considered a challenge to transform and evolve the labor market to serve an ever-shifting employment nature and a rapidly changing way of life. 


\section{REFERENCES}

Abdih, Yasser Stephan Danninger (2017). "What Explains the Decline of the U.S. Labor Share of Income? An Analysis of State and Industry Level Data,” IMF Working Paper No. WP/17/167.

Acemoglu, Daron and Pascual Restrepo (2016). “The Race Between Machine and Man: Implications of Technology for Growth, Factor Shares and Employment," NBER Working Paper No. 22252.

Arpaia, Alfonso, Esther Perez, and Karl Pichelmann (2009) "Understanding Labour Income Share Dynamics in Europe,” European Commission Economic Papers 379.

Autor, David, David Dorn, Lawrence Katz, Christina Patterson and John van Reenen (2017). "Concentrating on the Fall of the Labor Share," CEPR Discussion Papers 11810.

Autor, David, David Dorn, Lawrence F. Katz, Christina Patterson and John van Reenen (2017). "The Fall of the Labor Share and the Rise of Superstar Firms," NBER Working Paper No. 23396.

Blanchard, Olivier (1997) “The Medium Run,” Brookings Papers on Economic Activity, (2), pp. 89-158.

Ciminelli, Gabriele, Romain A Duval and Davide Furceri (2018). "Employment Protection Deregulation and Labor Shares in Advanced Economies,” IMF Working paper 18/186.

De Serres, Alain, Stefano Scarpetta, and Christine de la Maisonneuve (2002). "Sectoral Shifts in Europe and the United States: How They Affect Aggregate Labour Shares and the Properties of Wage Equations," OECD Economics Department Working Papers 326.

De Loecker, Jan and Jan Eeckhout (2017). "The Rise of Market Power and the Macroeconomic Implications," NBER Working Paper No. 23687.

Deakin, Simon, Jonas Malmberg and Prabirjit Sarkar (2014). "How Do Labor Laws Affect Unemployment and The Labor Share of National Income? The Experience of Six OECD Countries, 1970-2010," International Labour Review, 153 (1).

Elsby, Michael, Bart Hobijn and Ayseful Sahin (2013). "The Decline of the U.S. Labor Share," Brookings Papers on Economic Activity, 44(2), pp. 1-63.

European Commission (2007). "The Labour Income Share in the European Union,” Employment in Europe.

Fichtenbaum, Rudi (2011). "Do Unions Affect Labor's Share of Income: Evidence Using Panel Data," American Journal of Economics and Sociology, 70 (3), pp. 784-810.

Gomme, Paul and Jeremy Greenwood (1995). "On the Cyclical Allocation of Risk," Journal of Economic Dynamics and Control, 19 (1-2), pp. 91-124. 
Gomme, Paul and Peter Rupert (2004). “Measuring Labor's Share of Income," Federal Reserve Bank of Cleveland Policy Discussion Paper 7.

Grossman, Gene, Elhanan Helpman, Ezra Oberfield and Thomas Sampson (2017). "The Productivity Slowdown and the Declining Labor Share: A Neoclassical Exploration," CEP Discussion Papers dp1504.

Guscina, Anastasia (2007). "Effects of Globalization on Labor's Share in National Income,” IMF Working Papers 06/294.

Harrison, Anne (2002). 'Has Globalization Eroded Labor's Share? Some Cross-Country Evidence," mimeo.

Houngbonon, Georges Vivien and Pascal Da-Costa (2017). "Declining Labor Share and Innovation," Working Papers hal-01653816.

Jaumotte, Florence and Irina Tytell (2008). "How has the Globalization of Labor Affected the Labor Income Share in Advanced Countries?” IMF Working Papers 07/298.

Jayadev, Arjun (2007). "Capital Account Openness and the Labour Share of Income," Cambridge Journal of Economics, 31 (3), p. 423.

Karabarbounis, Loukas and Brent Neiman (2013). "The Global Decline of the Labor Share." Quarterly Journal of Economics, 129(1), pp. 61-103.

Koutentakis, Franciscos (2008). "The Effect of Temporary Contracts on Job Security of Permanent Workers," Economics Letters, vol. 101, iss. 3, pp. 220-222

Krueger, Alan (1999). “Measuring Labor's Share,” The American Economic Review, 89 (2), pp. 45-51.

Lawless, Martina and Karl Whelan (2011). "Understanding the Dynamics of Labor Shares and Inflation," Journal of Macroeconomics, 33 (2), pp. 121 - 136.

McKenzie, Richard and David Brackfield (2008) "The OECD System of Unit Labour Cost and Related Indicators," OECD Statistics Working Papers 4.

OECD (2009). "Compensation of Employees," National Accounts at a Glance. Pissarides, Christopher (2000). Equilibrium Unemployment Theory, MIT press, Reicher, Christopher (2011) "Matching Labor's Share in a Search and Matching Framework," Kiel Working Paper, Technical Report 1733.

Rios-Rull, Jose-Victor and Raul Santaeulalia-Llopis (2010) "Redistributive Shocks and Productivity Shocks,” Journal of Monetary Economics, 57 (8), pp. 931 - 948. 
Rodriguez, Francisco and Arjun Jayadev (2010). "The Declining Labor Share of Income," Human Development Research Papers HDRP-2010-36.

Ruiz, Carmen Garrido (2005). “Are Factor Shares Constant? An Empirical Assessment from a New Perspective," mimeo.

Schneider, Dorothee (2011a). "Monitoring, Information Technology and the Labor Share," Humboldt University Discussion Papers SFB649.

Schneider, Dorothee (2011b). "Bargaining, Openness, and the Labor Share," Humboldt University Discussion PapersSFB649.

Timmer, Marcel, Ton van Moergastel, Edwin Stuivenwold, Gerard Ypma, Mary O’Mahony, and Mari Kangasniemi (2007). "EU KLEMS Growth and Productivity Accounts: Version 1.0 - Part I: Methodology," EU KLEMS. 


\section{APPENDIX I. DATA DESCRIPTION}

Table A.1. List of Variables with Sources and Descriptions

\begin{tabular}{|c|c|c|}
\hline VARIABLES & CALCULATION & Source \\
\hline Labor share & $\begin{array}{l}\text { Ratio of total labor compensation to national vallue added divided } \\
\text { by employment share }\end{array}$ & Eurostat/Haver \\
\hline Unemployment gap & Percent deviation from eqilbrium unemployment rate & Eurostat \\
\hline Real producivity & Real labor productivity per hour & Eurostat \\
\hline $\begin{array}{l}\text { Involuntary part-time } \\
\text { employment }\end{array}$ & Share of involuntary part-time workers of total employment & Eurostat \\
\hline Self-employment share & Self-employment share of total employment & Eurostat \\
\hline Part-time employment & Part-time employment share of total employment & Eurostat \\
\hline Temporary contracts & Temporary contracts, thousands & Eurostat \\
\hline $\begin{array}{l}\text { Relative price of } \\
\text { investment goods }\end{array}$ & Total GFCF deflator/final consumption expenditure deflator & Eurostat/Haver \\
\hline Import pentation & Import penetration of emerging and developing economies & WEO \\
\hline Union penetration & Trade union density rate as percent of paid employment & OECD \\
\hline Unemployment benefits & Average net replacement rate over 60 months of unemployment & OECD \\
\hline Employment share & Strictness of individual and collective dismissals & OECD \\
\hline Forward link & Foreign value-added exports share of global value-added in GVC & OECD \\
\hline Backward link & Reexported value-added share of global value-added in GVC & OECD \\
\hline
\end{tabular}


Table A.2. Sector Categories

\begin{tabular}{ll}
\hline NAME & DEFINITION \\
\hline Total economy & Total economy \\
\hline Industry & Industry excluding construction \\
\hline Manufacturing & Manufacturing \\
\hline Construction & Construction \\
\hline Agriculture & Agriculture, forestry and fishing \\
\hline Finance and insurance & Finance and insurance \\
\hline Information and commucation & Information and commucation \\
\hline Trade, travel and food services & Trade, travel and food services \\
\hline Arts and creative srvices & Art, creation and other services \\
\hline Public adminsitration & Public administration, education, social work \\
\hline IT and professional services & Professional services, technology and administration \\
\hline Real estate & Real estate \\
\hline
\end{tabular}

Table A.3. Skill Categories

\begin{tabular}{|c|c|c|}
\hline CODE & DEFINITION & SKILL \\
\hline OC1 & Managers & \multirow{3}{*}{ High } \\
\hline OC2 & Professionals & \\
\hline $\mathbf{O C 3}$ & Technicians and associate professionals & \\
\hline OC4 & Clerical support workers & \multirow{4}{*}{ Medium } \\
\hline OC5 & Service and sales workers & \\
\hline OC6 & Skilled agricultural, forestry and fishery workers & \\
\hline OC7 & Craft and related trades workers & \\
\hline OC8 & Plant and machine operators and assemblers & \multirow{2}{*}{ Low } \\
\hline OC9 & Elementary occupations & \\
\hline
\end{tabular}

